\title{
Recent trends and variability in river discharge across northern Canada
}

\author{
Stephen J. Déry ${ }^{1}$, Tricia A. Stadnyk ${ }^{2}$, Matthew K. MacDonald ${ }^{1,2}$, and Bunu Gauli-Sharma ${ }^{1}$ \\ ${ }^{1}$ Environmental Science and Engineering Program, University of Northern British Columbia, \\ Prince George, British Columbia, Canada \\ ${ }^{2}$ Department of Civil Engineering, University of Manitoba, Winnipeg, Manitoba, Canada \\ Correspondence to: Stephen J. Déry (sdery@unbc.ca)
}

Received: 8 September 2016 - Published in Hydrol. Earth Syst. Sci. Discuss.: 13 September 2016 Accepted: 9 November 2016 - Published: 8 December 2016

\begin{abstract}
This study presents an analysis of the observed inter-annual variability and inter-decadal trends in river discharge across northern Canada for 1964-2013. The 42 rivers chosen for this study span a combined gauged area of $5.26 \times 10^{6} \mathrm{~km}^{2}$ and are selected based on data availability and quality, gauged area and record length. Inter-annual variability in river discharge is greatest for the eastern Arctic Ocean (coefficient of variation, $\mathrm{CV}=16 \%$ ) due to the $\mathrm{Ca}$ niapiscau River diversion into the La Grande Rivière system for enhanced hydropower production. Variability is lowest for the study area as a whole $(\mathrm{CV}=7 \%)$. Based on the Mann-Kendall test (MKT), no significant $(p>0.05)$ trend in annual discharge from 1964 to 2013 is observed in the Bering Sea, western Arctic Ocean, western Hudson and James Bay, and Labrador Sea; for northern Canada as a whole, however, a statistically significant $(p<0.05)$ decline of $102.8 \mathrm{~km}^{3}$ $25 \mathrm{yr}^{-1}$ in discharge occurs over the first half of the study period followed by a statistically significant $(p<0.05)$ increase of $208.8 \mathrm{~km}^{3} 25 \mathrm{yr}^{-1}$ in the latter half. Increasing (decreasing) trends in river discharge to the eastern Hudson and James Bay (eastern Arctic Ocean) are largely explained by the Caniapiscau diversion to the La Grande Rivière system. Strong regional variations in seasonal trends of river discharge are observed, with overall winter (summer) flows increasing (decreasing, with the exception of the most recent decade) partly due to flow regulation and storage for enhanced hydropower production along the Hudson and James Bay, the eastern Arctic Ocean and Labrador Sea. Flow regulation also suppresses the natural variability of river discharge, particularly during cold seasons.
\end{abstract}

\section{Introduction}

The pan-Arctic region is experiencing the highest rates of warming on Earth, substantially altering its environment and ecosystems (Serreze et al., 2000; Hinzman et al., 2005; Callaghan et al., 2011). As a result of this warming, significant declines in Arctic sea ice and pan-Arctic snow cover extent are being observed, inducing a positive snow-/ice-albedo feedback on warming (Serreze et al., 2007; Déry and Brown, 2007; Shi et al., 2011; Hernández-Henríquez et al., 2015). In turn, reductions in Arctic sea ice and pan-Arctic snow cover affect atmospheric circulation, with evidence emerging for a stronger meridional (rather than zonal) pattern in the Northern Hemisphere during recent years (Liu et al., 2012; Francis and Vavrus, 2012). The pan-Arctic hydrological cycle is also showing signs of change, as warmer conditions enable enhanced moisture transport into the pan-Arctic with concomitant increases in precipitation (Zhang et al., 2013) and intensification of the land surface hydrological cycle (Rawlins et al., 2010; Déry et al., 2009). The result has been increasing river discharge in the six principal rivers of Eurasia draining into the Arctic Ocean (Peterson et al., 2002; McClelland et al., 2004; Tananaev et al., 2016).

Findings from Peterson et al. (2002) for the Eurasian continent led many researchers to inquire whether similar trends were being observed in North America. Motivated by this, Déry et al. (2005a) conducted a comprehensive analysis of river discharge into the Hudson, James and Ungava bays spanning 1964-2000. In contrast to the findings of Peterson et al. (2002), Déry et al. (2005a) reported a recent $13 \%$ decline in river discharge to the Hudson, James, and Ungava bays. Déry and Wood (2005) expanded this effort 
to examine streamflow trends in 64 rivers draining all of northern Canada with the exception of the Canadian Arctic Archipelago (CAA). Over the period 1964-2003, Déry and Wood (2005) found a $10 \%$ decline in discharge for rivers draining northern Canada, consistent with recent decreases in precipitation over the study area. This unexpected result was attributed partly to the strong relationship between the Arctic Oscillation and river discharge in north-eastern Canada (Déry and Wood, 2004). Following this, McClelland et al. (2006) assembled data from both Eurasia and North America to provide a complete pan-Arctic view on recent trends in river discharge. Using a consistent study period and method for trend analysis, they concluded that pan-Arctic river discharge increased by $5.6 \mathrm{~km}^{3} \mathrm{yr}^{-1} \mathrm{yr}^{-1}$ from 1964 to 2000 , despite observed declines in river discharge to the Hudson, James and Ungava bays.

A decade has now passed since the work of Déry et al. (2005a), Déry and Wood (2004, 2005) and McClelland et al. (2006), offering the opportunity to reassess trends in river discharge across northern Canada, and to evaluate if trends are now more aligned with those observed in Eurasia. This effort also puts into context previous studies focused on hydrological variability and trends in northern Canada (e.g. Peters and Prowse, 2001; Woo and Thorne, 2003; Wang et al., 2015; Yang et al., 2015). This study therefore investigates trends and variability in discharge for 42 principal rivers draining northern Canada over a 50-year period (1964-2013). The research question motivating this effort is whether or not river discharge in northern Canada shows a continued decrease in the twenty-first century as first reported by Déry and Wood (2005). The effects of flow regulation and climate variability are both considered in our analyses, with emphasis on the inter-decadal seasonal variability in river discharge. Further, the discussion provides a comparison with previous studies, a review of anthropogenic effects on observed trends and variability in river discharge across northern Canada, and an overview of the potential physical impacts to the marine environment. A summary of the study's main findings and avenues for future work concludes the paper.

\section{Study area}

\subsection{Physical setting and climate}

A vast portion of Canada and parts of the northern United States drain northward to the Bering Strait, Arctic Ocean, Hudson and James Bay, Hudson Strait and Labrador Sea (Fig. 1). The CAA also drains into the Arctic Ocean but remains largely ungauged (Spence and Burke, 2008), with only two small rivers in this study (see Sect. 3.1). Six separate drainage basins are considered here (from west to east): Bering Strait, western Arctic Ocean, western Hudson and James Bay, eastern Hudson and James Bay, east- ern Arctic Ocean, and Labrador Sea. The gauged area totals $5.26 \times 10^{6} \mathrm{~km}^{2}$, more than half of the Canadian land surface area (Table 1). The Canadian provinces of British Columbia (BC), Alberta, Saskatchewan, Manitoba, Ontario, Québec and Newfoundland/Labrador along with the Yukon, Northwest and Nunavut territories form part of the study area. Some tributaries of the Nelson River drain a small portion of the north-central United States, namely in Montana, North and South Dakota, and Minnesota. Among the larger systems are the Yukon, Mackenzie, Back, Thelon-Kazan (hereafter collectively referred to as Chesterfield Inlet), Churchill (Manitoba), Nelson, Hayes (Manitoba), Albany, Moose, La Grande, Koksoak and Churchill (Labrador) rivers (Table 1).

The vegetation and land cover varies markedly across the vast area drained by northern Canada's rivers. The northern Rocky Mountains with peaks approaching $4000 \mathrm{~m}$ above sea level in the headwaters of the Yukon, Mackenzie and Nelson rivers have bare rocks, glaciers and snow with limited vegetation such as lichens and mosses. Grasslands of the central Canadian Prairies and the American northern Great Plains subject to intense agricultural activity cover the central portion of the Nelson River basin. Further north and to the east, boreal and taiga forests of the Canadian Shield span a vast portion of the study area. Arctic tundra underlain by permafrost covers the northernmost portions of these drainage basins. Several large bodies of water including Great Bear, Great Slave and Reindeer lakes, as well as with the lakes Athabasca, Manitoba, Winnipegosis and Winnipeg and countless smaller lakes, ponds and wetlands, form natural reservoirs in this system. Large artificial reservoirs developed for hydropower production exist in the study area as well, most prominently in the La Grande Rivière, Nelson, and Churchill (both in Manitoba and Newfoundland/Labrador) river basins (see Sect. 2.2 and Table 1).

The climate also varies substantially across the study area. In the mountainous terrain of north-western Canada, mean annual air temperatures remain below $0{ }^{\circ} \mathrm{C}$ with abundant snowfall dominating the form of precipitation. The Canadian Prairies and northern American Great Plains to the lee of the western Cordillera are relatively warm and dry (mean annual total precipitation of $300-500 \mathrm{~mm}$ ), with most of the precipitation occurring during summer. The boreal and taiga forests experience relatively cool and wet climate regimes (mean annual total precipitation of $500-1000 \mathrm{~mm}$ ), with both abundant rainfall and snowfall. On the Arctic tundra, cold temperatures (mean annual air temperature $<-10^{\circ} \mathrm{C}$ ) and snowfall dominate the climate. The seasonal snow cover typically lasts 4-6 months on the Canadian Prairies, $\sim 6$ months in the boreal forest and 6-8 months in Arctic tundra and mountainous terrain (McKay and Gray, 1981). Given these climate regimes, most unregulated rivers of northern Canada exhibit a nival regime, with low flows in winter when water is stored in the seasonal snowpack, then high flows during the snowmelt-driven freshet in spring and early summer (Déry et al., 2005a). A summer recession driven by high evapotran- 
Table 1. List of 42 rivers (from west to east) and their tributaries (italicised) that discharge into six drainage basins in northern Canada with geographical coordinates of the recording gauge nearest to the mouth, number and volume of artificial reservoirs, contributing area that is gauged, the mean, standard deviation (SD), coefficient of variation (CV) and trend in annual river discharge, 1964-2013. Reservoir information is sourced from Lehner et al. (2011).

\begin{tabular}{|c|c|c|c|c|c|c|c|c|c|c|}
\hline Region & River & $\begin{array}{l}\text { Lat } \\
\left({ }^{\circ} \mathrm{N}\right)\end{array}$ & $\begin{array}{l}\text { Long } \\
\left({ }^{\circ} \mathrm{W}\right)\end{array}$ & $\begin{array}{l}\text { Number } \\
\text { of } \\
\text { reservoirs }\end{array}$ & $\begin{array}{l}\text { Reservoir } \\
\text { volume } \\
\left(\mathrm{km}^{3}\right)\end{array}$ & $\begin{array}{l}\text { Gauged area } \\
\left(\mathrm{km}^{2}\right)\end{array}$ & $\begin{array}{l}\text { Mean } \\
\left(\mathrm{km}^{3}\right. \\
\left.\mathrm{yr}^{-1}\right)\end{array}$ & $\begin{array}{l}\text { SD } \\
\left(\mathrm{km}^{3}\right. \\
\left.\mathrm{yr}^{-1}\right)\end{array}$ & $\mathrm{CV}$ & $\begin{array}{l}\text { Trend } \\
\left(\mathrm{km}^{3}\right. \\
\left.50 \mathrm{yr}^{-1}\right)\end{array}$ \\
\hline \multirow[t]{4}{*}{ Bering Sea } & Yukon & 64.79 & 141.20 & 1 & 0.3 & 288000 & 77.28 & 9.48 & 0.12 & 3.23 \\
\hline & Porcupine & 67.42 & 140.89 & - & 0 & 58900 & 10.57 & 2.49 & 0.24 & -1.26 \\
\hline & Firth & 69.33 & 139.57 & - & 0 & 5700 & 1.21 & 0.23 & 0.19 & -0.02 \\
\hline & $\begin{array}{l}\text { Mackenzie } \\
\text { Mackenzie } \\
\text { Peel }\end{array}$ & $\begin{array}{l}67.46 \\
67.24\end{array}$ & $\begin{array}{l}133.75 \\
134.89\end{array}$ & 8 & 75.7 & $\begin{array}{l}1749700 \\
1679100 \\
70600\end{array}$ & 311.38 & 32.18 & 0.10 & 20.87 \\
\hline \multirow{9}{*}{$\begin{array}{l}\text { Western } \\
\text { Arctic } \\
\text { Ocean }\end{array}$} & Anderson & 68.63 & 128.42 & - & 0 & 57800 & 4.72 & 1.39 & 0.30 & 0.06 \\
\hline & Coppermine & 67.23 & 115.89 & - & 0 & 46200 & 8.77 & 1.64 & 0.19 & -0.73 \\
\hline & Tree & 67.64 & 111.90 & - & 0 & 5810 & 1.11 & 0.24 & 0.22 & -0.05 \\
\hline & Burnside & 66.73 & 108.81 & - & 0 & 16800 & 4.20 & 0.98 & 0.23 & 0.06 \\
\hline & Ellice & 67.71 & 104.14 & - & 0 & 16900 & 2.82 & 0.64 & 0.23 & 0.08 \\
\hline & Back & 66.09 & 96.51 & - & 0 & 93900 & 15.52 & 3.17 & 0.20 & -0.40 \\
\hline & Freshwater Creek & 69.13 & 104.99 & - & 0 & 1490 & 0.14 & 0.04 & 0.26 & 0.00 \\
\hline & $\begin{array}{l}\text { Chesterfield } \\
\text { Inlet }\end{array}$ & & & - & 0 & 224000 & 41.28 & 6.93 & 0.17 & 4.86 \\
\hline & Thelon & 64.77 & 97.05 & & & 154000 & & & & \\
\hline \multirow{12}{*}{$\begin{array}{l}\text { Western } \\
\text { Hudson and } \\
\text { James Bay }\end{array}$} & Thlewiaza & 60.78 & 98.77 & - & 0 & 27000 & 6.82 & 0.81 & 0.12 & 0.00 \\
\hline & Seal & 58.89 & 96.27 & - & 0 & 48200 & 11.49 & 2.46 & 0.21 & 1.15 \\
\hline & $\begin{array}{l}\text { Churchill } \\
\text { Churchill } \\
\text { Deer }\end{array}$ & $\begin{array}{l}58.12 \\
58.01\end{array}$ & $\begin{array}{l}94.62 \\
94.19\end{array}$ & Partial dive & $\begin{array}{l}\text { rsion to Nelson } \\
\text { River }\end{array}$ & $\begin{array}{l}290880 \\
289000 \\
1880 \\
\end{array}$ & 18.90 & 13.25 & 0.70 & $-9.31^{*}$ \\
\hline & $\begin{array}{l}\text { Nelson } \\
\text { Angling } \\
\text { Limestone } \\
\text { Nelson } \\
\text { Weir }\end{array}$ & $\begin{array}{l}56.67 \\
56.51 \\
56.37 \\
57.20\end{array}$ & $\begin{array}{l}93.64 \\
94.21 \\
94.63 \\
93.45\end{array}$ & 72 & 95.0 & $\begin{array}{l}1125520 \\
1560 \\
3270 \\
1100000 \\
2190\end{array}$ & 102.70 & 22.63 & 0.22 & 18.70 \\
\hline & Hayes & 56.43 & 92.79 & - & 0 & 103000 & 19.71 & 4.96 & 0.25 & -2.32 \\
\hline & Severn & 55.37 & 88.32 & - & 0 & 94300 & 21.90 & 5.59 & 0.26 & 0.02 \\
\hline & $\begin{array}{l}\text { Winisk } \\
\text { Shamattawa } \\
\text { Winisk }\end{array}$ & $\begin{array}{l}54.28 \\
54.52\end{array}$ & $\begin{array}{l}85.65 \\
87.23\end{array}$ & - & 0 & $\begin{array}{l}54710 \\
4710 \\
50000\end{array}$ & 15.24 & 4.69 & 0.31 & -2.32 \\
\hline & Ekwan & 53.80 & 84.92 & - & 0 & 16900 & 2.76 & 0.69 & 0.25 & 0.00 \\
\hline & Attawapiskat & 53.09 & 85.01 & - & 0 & 36000 & 11.43 & 3.33 & 0.29 & -1.54 \\
\hline & Albany & 51.33 & 83.84 & 2 & 1.2 & 118000 & 31.77 & 8.06 & 0.25 & 2.14 \\
\hline & $\begin{array}{l}\text { Moose } \\
\text { Abitibi } \\
\text { Kwataboahegan } \\
\text { Moose } \\
\text { North French }\end{array}$ & $\begin{array}{l}50.60 \\
51.16 \\
50.81 \\
51.07\end{array}$ & $\begin{array}{l}81.41 \\
80.86 \\
81.29 \\
80.76\end{array}$ & 3 & 2.1 & $\begin{array}{l}98530 \\
27500 \\
4250 \\
60100 \\
6680\end{array}$ & 39.01 & 7.28 & 0.19 & $-6.58^{*}$ \\
\hline & $\begin{array}{l}\text { Harricana } \\
\text { Harricana } \\
\text { Turgeon }\end{array}$ & $\begin{array}{l}49.95 \\
49.98\end{array}$ & $\begin{array}{l}78.72 \\
79.09\end{array}$ & - & 0 & $\begin{array}{l}21200 \\
10000 \\
11200\end{array}$ & 7.75 & 1.00 & 0.13 & 0.02 \\
\hline \multirow{8}{*}{$\begin{array}{l}\text { Eastern } \\
\text { Hudson and } \\
\text { James Bay }\end{array}$} & Nottaway & 50.13 & 77.42 & - & 0 & 57500 & 32.27 & 5.32 & 0.16 & -2.79 \\
\hline & Broadback & 51.18 & 77.43 & - & 0 & 17100 & 10.03 & 1.53 & 0.15 & 0.66 \\
\hline & Rupert & 51.44 & 76.86 & $\begin{array}{r}\text { Partial di } \\
\text { G }\end{array}$ & $\begin{array}{l}\text { version to } \mathrm{La} \\
\text { rande }\end{array}$ & 40900 & 25.32 & 4.93 & 0.19 & -2.99 \\
\hline & Pontax & 51.53 & 78.09 & - & 0 & 6090 & 3.12 & 0.37 & 0.12 & 0.00 \\
\hline & Eastmain & 52.24 & 78.07 & $\begin{array}{r}\text { Partial di } \\
\text { G }\end{array}$ & $\begin{array}{l}\text { version to } \mathrm{La} \\
\text { rande }\end{array}$ & 44300 & 12.11 & 12.73 & 1.05 & -0.63 \\
\hline & La Grande & 53.72 & 78.57 & 7 & 205.4 & 96600 & 84.22 & 24.38 & 0.29 & $14.27^{*}$ \\
\hline & $\begin{array}{l}\text { Grande Rivière de la } \\
\text { Baleine }\end{array}$ & 55.29 & 77.59 & $\begin{array}{r}\text { Partial di } \\
\text { G }\end{array}$ & $\begin{array}{l}\text { version to } \mathrm{La} \\
\text { rande }\end{array}$ & 43200 & 19.61 & 2.60 & 0.13 & $-3.78^{*}$ \\
\hline & Nastapoca & 56.86 & 76.21 & - & 0 & 12500 & 7.94 & 0.91 & 0.11 & 0.00 \\
\hline \multirow{5}{*}{$\begin{array}{l}\text { Eastern } \\
\text { Arctic Ocean }\end{array}$} & Aux Feuilles & 58.64 & 70.42 & - & 0 & 41700 & 17.62 & 2.14 & 0.12 & -0.40 \\
\hline & $\begin{array}{l}\text { Koksoak } \\
\text { Caniapiscau } \\
\text { Aux Mélèzes }\end{array}$ & $\begin{array}{l}57.42 \\
58.64\end{array}$ & $\begin{array}{l}69.25 \\
70.42\end{array}$ & $\begin{array}{r}\text { Partial di } \\
\text { G }\end{array}$ & $\begin{array}{l}\text { version to } \mathrm{La} \\
\text { rande }\end{array}$ & $\begin{array}{l}127200 \\
84500 \\
42700\end{array}$ & 55.57 & 14.76 & 0.27 & -7.01 \\
\hline & À la Baleine & 57.88 & 67.58 & - & 0 & 29800 & 16.02 & 1.96 & 0.12 & $-1.74^{*}$ \\
\hline & George & 58.15 & 65.84 & - & 0 & 35200 & 23.73 & 3.07 & 0.13 & -0.33 \\
\hline & Sylvia Grinnell & 63.77 & 68.58 & - & 0 & 2980 & 1.07 & 0.21 & 0.20 & 0.00 \\
\hline Labrador & Naskaupi & 54.13 & 61.43 & - & 0 & 4480 & 6.00 & 1.02 & 0.17 & $-1.15^{*}$ \\
\hline \multirow[t]{4}{*}{ Sea } & Churchill & 53.25 & 60.79 & 4 & 49.5 & 92500 & 56.29 & 7.20 & 0.13 & -2.58 \\
\hline & Eagle & 53.53 & 57.49 & - & 0 & 10900 & 8.02 & 1.29 & 0.16 & -0.47 \\
\hline & Alexis & 52.65 & 56.87 & - & 0 & 2310 & 1.66 & 0.22 & 0.13 & 0.00 \\
\hline & Ugjoktok & 55.23 & 61.30 & - & 0 & 7570 & 5.06 & 0.74 & 0.15 & -0.07 \\
\hline
\end{tabular}




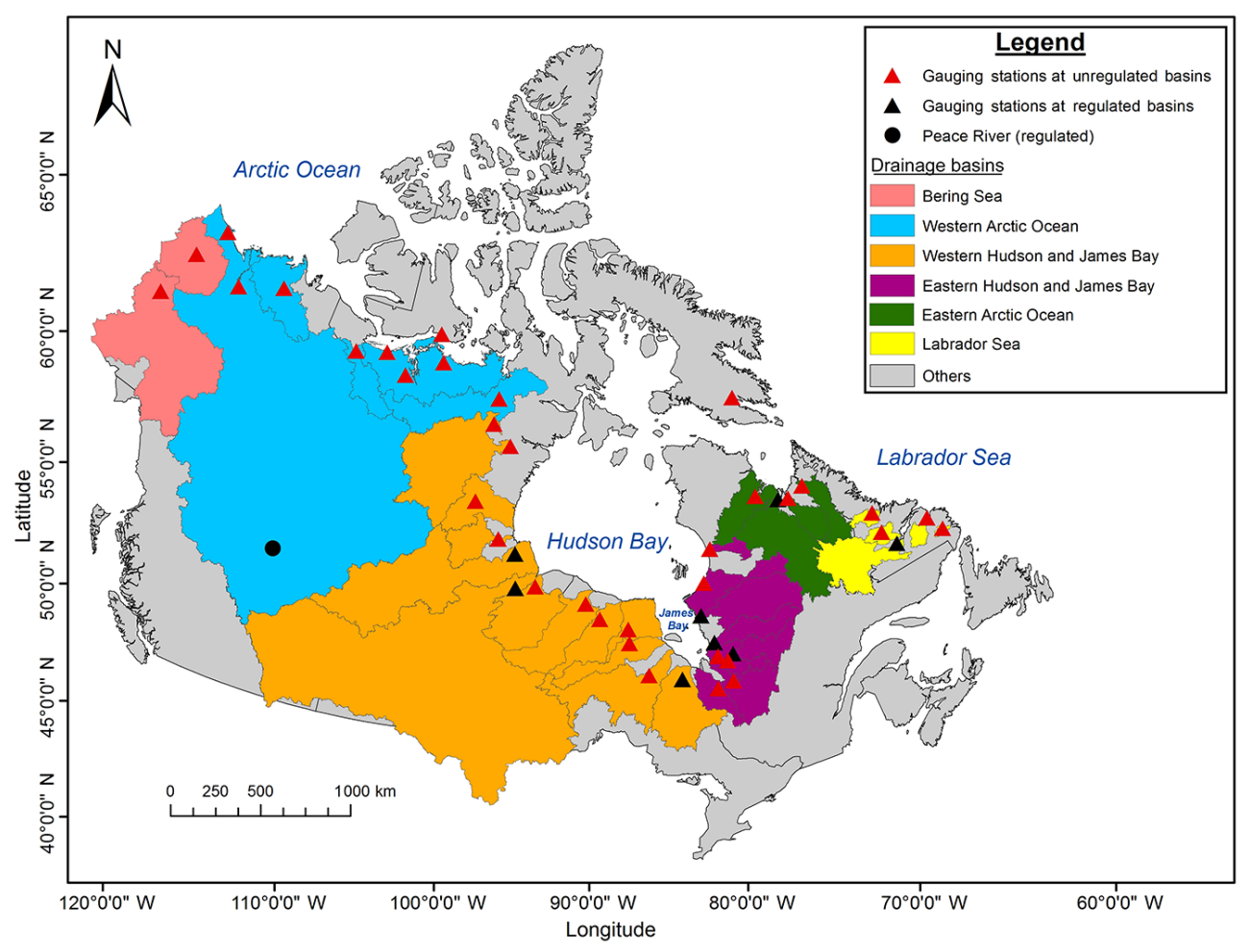

Figure 1. Map of the six major basins draining northern Canada and parts of the northern United States as well as the spatial distribution of hydrometric gauges used in this study.

spiration rates follows, with possible secondary peak flows in fall caused by the frequent passage of synoptic storms (Déry et al., 2005a). High flows at times occur in summer as well in small creeks and rivers associated with severe convective activity or at larger scales when associated with intense synoptic storms. In contrast, some regulated systems exhibit low temporal variability in flows with daily fluctuations arising from hydropower demand and generation (Woo et al., 2008; Déry et al., 2011). In areas affected by permafrost, hydrological responses are relatively rapid given the limited infiltration capacity of frozen soils (Woo, 1986). Glaciers in the northern Rocky Mountains and other mountain chains also supply additional meltwater in late summer and early fall, particularly during warm, dry years (Marshall et al., 2011).

\subsection{Regulated systems}

Several rivers in the study area are not only regulated for hydropower production but also for flood protection, irrigation, industrial and recreational purposes, and are thus considered moderately to strongly fragmented (Dynesius and Nilsson, 1994). The highly fragmented Nelson River basin has a long history of hydropower development, with hydroelectric generation beginning in 1906 on the Pinawa Channel of the Winnipeg River system (Manitoba Hydro, 1998). Since then there has been a proliferation of dams constructed along the Nelson River's main stem and several of its tributaries.
Reservoirs such as the artificial Lake Diefenbaker (formerly a section of the South Saskatchewan River) and the natural Lake Winnipeg and Southern Indian Lake allow for seasonal water storage in this system that is managed depending on inflows, hydropower demand, flood protection and governmental regulations. In 1976, Manitoba's Churchill River was partially diverted through the Rat and Burntwood rivers (with water releases controlled at the Notigi Control Structure) for enhanced hydropower production on the lower Nelson River. An additional capacity of $7 \mathrm{~km}^{3}$ of water storage in the Southern Indian Lake was developed in the process as it thereafter became managed (Déry and Wood, 2005). Since then, approximately $75 \%$ of the annual flows into Manitoba's Churchill River have been diverted into the lower Nelson River, greatly diminishing the Churchill River's annual inflows into the Hudson Bay (Newbury et al., 1984).

Another highly fragmented system is La Grande Rivière where the massive James Bay hydroelectric complex was developed in the mid-1970s by Hydro-Québec (HernándezHenríquez et al., 2010). As a result of this, several large reservoirs with a storage capacity now surpassing $200 \mathrm{~km}^{3}$ have been built and are managed depending on hydropower demand and consumption. Development of the James Bay hydroelectric complex has diverted portions of the Eastmain and Opinaca rivers starting in 1980, the upper Caniapiscau River (a major tributary of the Koksoak River) in 1982 
and the Rupert River in 2009 to La Grande Rivière's basin (Déry et al., 2005a). Of note, the Caniapiscau River diversion $\left(\right.$ area $\left.=36900 \mathrm{~km}^{2}\right)$ induces an inter-basin transfer of $45 \%$ of its flows or $748 \mathrm{~m}^{3} \mathrm{~s}^{-1}$ from the eastern Arctic Ocean toward the eastern Hudson and James Bay system (Roy and Messier, 1989). The overall drainage basin area for La Grande Rivière has now effectively doubled in size to surpass $200000 \mathrm{~km}^{2}$ (Roy and Messier, 1989; Hydro-Québec, 2008). Just to the east of the Caniapiscau Reservoir lies Newfoundland and Labrador's Churchill River that is also managed for hydropower production. Construction of hydroelectric facilities at Churchill Falls began in 1967 and they have been fully operational since 1974 . This has led to the creation of the Smallwood Reservoir with a water storage capacity of $33 \mathrm{~km}^{3}$ (Déry and Wood, 2005). In Ontario, the Moose River and its many tributaries are highly fragmented by a series of 40 hydroelectric dams with development beginning in 1911 (Benke and Cushing, 2005). However, these are mainly runof-river projects with little storage capacity, exerting less influence on downstream flows. While the Mackenzie River's main stem is unregulated, one of its major tributaries, the Peace River (basin area $\sim 293000 \mathrm{~km}^{2}$ ), remains managed for hydropower production. Construction of the W. A. C. Bennett Dam from 1968 to 1972 created the Williston Reservoir with a storage capacity of $74.3 \mathrm{~km}^{3}$. This has led to an attenuation of the seasonal cycle in downstream flows, affecting the recharge of the Peace-Athabasca Delta (Rasouli et al., 2013). Other rivers moderately affected by fragmentation in northern Canada include the Grande Rivière de la Baleine, Nottaway and Albany rivers (Dynesius and Nilsson, 1994).

\section{Data and methods}

\subsection{Data and study period}

This study examines 42 main rivers of northern Canada for which daily hydrometric data from gauging stations are available (Table 1). The principal source of the hydrometric data remains the Water Survey of Canada (http://www.ec. gc.ca/rhc-wsc/), with supplemental data from the Direction d'Expertise Hydrique du Québec (http://www.cehq.gouv.qc. $\mathrm{ca} /$ ) from 2000 to 2013 for rivers in that province. Manitoba Hydro and Hydro-Québec also provide daily hydrometric data for the regulated Nelson River and La Grande Rivière, respectively. Gauges furthest downstream on a river's main stem are chosen to obtain the maximum spatial coverage and most accurate estimates of total inflows to the coastal ocean. Additional criteria used for the selection of the 42 rivers are (1) > 30 years of data availability over 1964-2013 (the study period), (2) gauged area $>1000 \mathrm{~km}^{2}$ and (3) outlets to the coastal ocean in northern Canada. Note that only the Canadian portions of the Yukon River and its tributary the Porcupine River are included here, although additional hydrometric data are available for the former near its outlet to the Bering Strait in Alaska (e.g. Walwoord and Striegl, 2007). This is to establish the direct contribution of Canadian rivers to discharge into the coastal ocean. Apart from the 42 rivers selected for this study, additional hydrometric data for tributaries that flow downstream from a gauge on a river's main stem are also included in the development of the discharge time series (Table 1). In this case, results are presented collectively and the systems are then referred to by the river's main stem. For example, results for the Peel River are added to the Mackenzie River (at Arctic Red River) as their hydrometric gauges are upstream of the confluence of these two rivers. Section 3.2.1 provides details of the construction of the river discharge time series when such situations arise.

While discharge measurements remain highly constrained observational data, errors arise nonetheless during the collection process (Lammers et al., 2001; Shiklomanov et al., 2006). Sources for these errors range from the collection method, sampling frequency, environmental conditions (e.g. under ice cover, backwater effects during ice jams, flood events, beaver dams and vegetation) and the local geography (presence or absence of a flood plain). Errors in measurements typically range from \pm 2 to $5 \%$ in the absence of both a flood plain and an ice cover (Lammers et al., 2001); however, errors in measurement increase to $\pm 5-12 \%$ in the presence of either a flood plain and/or an ice cover. Errors may reach or even exceed these values during peak and low flows as well (Pelletier, 1988; Di Baldassarre and Montanari, 2009). While a comprehensive analysis of errors in discharge measurements is beyond the scope of this work, it is assumed this study's observational data are subject to similar errors reported by Pelletier (1988), Lammers et al. (2001), Shiklomanov et al. (2006) and Di Baldassarre and Montanari (2009). Caution is also needed in interpreting results for the Thelon and Kazan rivers (Chesterfield Inlet), as a change in recording methodology in the mid-1980s may lead to spurious trends in that system (Déry et al., 2011). Finally, flow measurement error likely decreases over time in this study, as sampling methods become more reliable and increasingly more automated.

The study period covers 50 years, starting in 1964 and ending in 2013. While long-term hydrological records are necessary to distinguish the impacts of decadal climate variability from climate change on streamflow, northern Canada has a paucity of hydrometric data prior to 1964 (Mlynowski et al., 2011). The rapid expansion of northern Canada's hydrometric network in the mid-1960s, particularly on main stem rivers with gauging stations installed near their outlets, allows the study period here to begin in 1964. There are relatively long-term (century scale) hydrometric data in more southern tributaries of some systems, however, including the Mackenzie, Nelson and Moose rivers. Availability of long-term hydrometric data for rivers draining the CAA remains limited to the Freshwater Creek near Cambridge Bay on Victoria Island (gauged area of $1490 \mathrm{~km}^{2}$ draining into 
the western Arctic Ocean) and the Sylvia Grinnell River near Iqaluit on Baffin Island (gauged area $2980 \mathrm{~km}^{2}$ draining into the eastern Arctic Ocean). Thus, only $0.3 \%$ of the CAA has available hydrometric data, implying the results are not representative of this vast region where glaciers and ice caps are in rapid retreat (Gardner et al., 2011). In fact, most of northern Canada falls well below the World Meteorological Organization (WMO) standards for hydrometric gauge density, imposing limitations on this effort (Coulibaly et al., 2013). More recent hydrometric data (post 2013) remain largely unavailable due to ongoing quality control processes by various governmental agencies; thus, only operational (historical) data from the Water Survey of Canada and its provincial/territorial partners are used in this study since provisional (near-real-time) data posted online have not yet undergone quality control and analysis.

\subsection{Methods}

\subsubsection{Time series construction}

Following quality control and analysis, daily streamflow data (in $\mathrm{m}^{3} \mathrm{~s}^{-1}$ ) are compiled and transformed to seasonal and annual time series of discharge (in $\mathrm{km}^{3} \mathrm{yr}^{-1}$ ) for 42 rivers in northern Canada (Table 1). The four seasons are taken here as winter (January to March), spring (April to June), summer (July to September) and fall (October to December). This selection is somewhat arbitrary since the actual duration of each season varies greatly from region to region (e.g. wintertime conditions can easily persist for 6 or more months on the Arctic tundra). For some systems (most notably the Mackenzie, Nelson and Moose rivers), hydrometric data from tributaries downstream of main stem gauging stations are included in the database (such as the Peel River with the Mackenzie River). Data from these tributaries are then added to the concurrent time series for the river's main stem and are referred to simply by the principal waterway. Streamflow data for regulated or partially diverted rivers are not naturalised in this study. Motivation for this strategy lies in the study's main objective of quantifying actual discharge to the coastal ocean, irrespective of the effects of climate change, land use and land cover change, and flow regulation. Likewise, discharge data are not adjusted to account for the filling of large reservoirs such as in the La Grande Rivière, Nelson and Mackenzie (Peace River) systems, leading to a better understanding of the impacts of changing river discharge in northern Canada.

Construction of the discharge time series when gaps exist follows a two-step process (as needed) similar to Déry et al. (2005a). First, daily hydrometric data from the gauging station furthest downstream and near a river's outlet to the coastal ocean are used to represent the watershed. If unavailable, then an upstream gauge is used and streamflow data are adjusted to account for the missing contributing area (Déry et al., 2005a). In several instances, this includes combining data from two or more tributaries upstream from a main stem river's gauge (e.g. the Waswanipi and Bell rivers for the Nottaway River after 1982). When upstream gauges remain unavailable, a secondary step is taken to fill in data gaps. Here a daily climatology of streamflow (or mean annual hydrograph) is constructed based on the availability of data over the period of record. Missing data on a given day are then infilled with the daily mean value of streamflow over the available period of record. For Manitoba's Churchill River and Québec's Eastmain, Caniapiscau and Rupert rivers, separate climatologies of daily streamflow are constructed for the periods prior to and after flow diversions (see Sect. 2.2). This is a more appropriate gap-filling strategy for these rivers prior to and subsequent to diverted flows. The impacts of this gapfilling strategy on discharge trend and statistical analyses are discussed in Sect. 3.2.2.

There are substantial gaps in some of the discharge time series that are infilled. Most notable are gaps in the first few years of the study period as the network of hydrometric gauges was being enhanced, particularly in remote rivers of northern Canada. Between 1970 and 1990, the gauged area in rivers of northern Canada stabilised until some notable reductions in northern Ontario in the mid- to late 1990s and in northern Québec in the early to mid-2000s (Mlynowski et al., 2011). Decreases in gauged area persisted into the late 2000s, with a steady recovery since then (Coulibaly et al., 2013). The most prominent data gaps in northern Ontario are in the Ekwan River (1964-1966 and 1996-2010), the Severn River (1995-2006), the Albany, Winisk and Attawapiskat rivers (1996-1998), and the main stem Moose River (19982001). In northern Québec, pronounced gaps exist for all rivers draining into the eastern Arctic Ocean, primarily between 2000 and 2008. Furthermore, data downstream of the diverted flows of the Eastmain and Rupert rivers are lacking after 2005 and infilled with estimates of mean daily flow accounting for their partial diversions to La Grande Rivière. Hydrometric data for some smaller systems (e.g. the Freshwater Creek, and the Firth, Ellice and Sylvia Grinnell rivers) in Canada's northern territories are often only seasonally available. In absence of wintertime hydrometric data, daily discharge is assumed to be zero as these rivers likely freeze to their beds (e.g. Woo, 1986). Following these steps, time series are aggregated to six regional drainage basins based on the bodies of water they drain into: the Bering Strait (Canadian portion only), western Arctic Ocean, western Hudson and James Bay, eastern Hudson and James Bay, eastern Arctic Ocean (Ungava Bay/Hudson Strait), and Labrador Sea (see Fig. 1).

\subsubsection{Statistical and trend analyses}

Statistics of the mean, standard deviation (SD) and coefficient of variation (CV, which is equal to $\mathrm{SD} /$ mean) in annual and seasonal river discharge for each of the six drainage basins and total gauged area are first computed. Linear trend 
analysis follows the approach of Déry et al. (2005a, 2011) by employing the Mann-Kendall test (MKT; Mann, 1945; Kendall, 1975). The Sen's slope estimator provides the magnitude of the trend while a probability value ( $p$ value) of 0.05 quantifies statistically significant trends in this work. If monotonic trends are statistically significant, time series of annual and seasonal river discharge are tested for serial correlation. If the lag 1 autoregression for either annual or seasonal time series of river discharge attains $p<0.05$, then "pre-whitening" of the data following Yue et al. (2002) is performed. Seasonal autocorrelations in total annual discharge across northern Canada are also presented. Both temporal analyses for the six regions and all of northern Canada and spatial analyses for each of the 42 rivers are presented.

Gap-filling can influence the magnitude of MKT trends. Replacing missing data by climatological values reduces the variability (both the SD and $\mathrm{CV}$ ) in discharge, attenuating linear trends. While overall annual and seasonal discharge statistics are assessed only from the available records, care must be used in interpreting linear trends, particularly in systems where large gaps arise (see Sect. 3.2.1). Other rivers exhibit strong trends that appear from inter-basin diversions, which must also be interpreted in the appropriate context. Additional uncertainty in the trend analyses arises from potential shifts in the timing of streamflow that may otherwise be missed by the gap-filling process; however, examination of results based on annual and seasonal river discharge data attenuates this issue.

Additional analyses on seasonal variability of river discharge for each decade (1964-1973, 1974-1983, 1984-1993, 1994-2003 and 2004-2013) are performed for eight regulated $(\mathrm{R})$ and seven "matching" unregulated $(\mathrm{U})$ rivers. Chosen for this comparison are the Nelson and Churchill rivers in Manitoba (R) with the Seal and Hayes rivers (U), the Moose (R) and Albany (U) rivers, the Rupert and Eastmain rivers (R) with the Nottaway (U) River, La Grande Rivière $(\mathrm{R})$ and Grande Rivière de la Baleine (U), the Koksoak (through its tributary the Caniapiscau, R) and à la Baleine (U) rivers, and the Churchill River in Labrador (R) and Eagle River (U). The matching unregulated systems are selected for their proximity to corresponding regulated systems, similar climatic and hydrological regimes, and comparable physiography and drainage areas. Box-and-whisker plots showing the median, inter-quantile ranges and the 5th and 95th percentiles in the $\mathrm{CV}$ of seasonal river discharge per decade are contrasted for regulated and matching unregulated systems. For proper interpretation of this inter-decadal analysis, it is important to review the timeline of hydroelectric infrastructure development in northern Canada. The majority of hydroelectric development occurred during the 1974-1983 decade, focusing on the construction of dams and diversions in the Nelson River and La Grande Rivière systems. The 19641973 period denotes the pre-regulation period in this study (although the Nelson and Moose rivers were fragmented prior to 1964); 1974-1983 represents the construction pe- riod when large dams and diversions on the Churchill, Eastmain, La Grande Rivière and Koksoak (Caniapiscau) systems were introduced, and development of the Nelson River continued. Therefore, 1984-2013 marks the post-regulation period (however, regulation [diversion] of the Rupert River did not commence until the 2004-2013 decade). Finally, the 1964-2013 climatological hydrographs based on observed daily river discharge are then constructed and presented for each of the six regional drainage basins of interest.

\section{Results}

\subsection{Temporal analyses}

Table 1 lists comprehensive statistics and trend analyses for this study's 42 rivers over 50 years. Mean annual discharge is the highest in the Mackenzie $\left(311.4 \mathrm{~km}^{3} \mathrm{yr}^{-1}\right)$, Nelson (102.7 $\left.\mathrm{km}^{3} \mathrm{yr}^{-1}\right)$, La Grande Rivière $\left(84.2 \mathrm{~km}^{3} \mathrm{yr}^{-1}\right)$ and Yukon $\left(77.3 \mathrm{~km}^{3} \mathrm{yr}^{-1}\right)$ rivers. With the recent diversion of the Rupert River, mean annual discharge in La Grande Rivière regularly exceeds $100 \mathrm{~km}^{3} \mathrm{yr}^{-1}$, with a record $129.2 \mathrm{~km}^{3} \mathrm{yr}^{-1}$ in 2013 . Variability (expressed by the $\mathrm{CV}$ ) in annual discharge remains relatively low (high) in the large (small) basins. The CV in annual discharge remains relatively high in unregulated rivers of the western Arctic Ocean and western Hudson and James Bay with a maximum of $70 \%$ for Manitoba's Churchill River where diverted and regulated flows enhance year-to-year variability. Few statistically significant trends arise for the study period, with the notable exception of rivers affected by diversions and flow regulation.

Table 2 provides aggregated statistics of the mean, SD, $\mathrm{CV}$ and trend of annual discharge for six regions of northern Canada from 1964 to 2013. Mean annual discharge ranges from $77.0 \mathrm{~km}^{3} \mathrm{yr}^{-1}$ in the Labrador Sea to $349.9 \mathrm{~km}^{3} \mathrm{yr}^{-1}$ in the western Arctic Ocean, with a total of $1154.1 \mathrm{~km}^{3} \mathrm{yr}^{-1}$ for the gauged area of northern Canada. Considerable interannual variability in discharge exists, with the $\mathrm{CV}$ ranging spatially from 9 to $16 \%$, although this value diminishes to $7 \%$ for the system as a whole. Relatively constant discharge to the eastern Arctic Ocean in the 2000s arises from large data gaps in this region and the infilling strategy used in the present study (Fig. 2). There is no significant trend in the 1964-2013 annual discharge to the Bering Strait, western Arctic Ocean, western Hudson and James Bay and Labrador Sea. Nonetheless, a 5-year-running mean applied to the discharge time series has shown rising annual discharge since 1990 for the western Hudson and James Bay. High flows in the late 2000s including record-high annual river discharge $\left(438.8 \mathrm{~km}^{3} \mathrm{yr}^{-1}\right)$ to the western Hudson and James Bay in 2005, follows near-record low annual amounts (263.1 km $\mathrm{kr}^{3}$ ) in 2003. Similarly, a reversal from record-low river discharge $\left(258.5 \mathrm{~km}^{3} \mathrm{yr}^{-1}\right.$ in 1995) precedes record-high river discharge $\left(419.0 \mathrm{~km}^{3} \mathrm{yr}^{-1}\right.$ in 1997) to the western Arctic Ocean. Persistent low annual discharge 


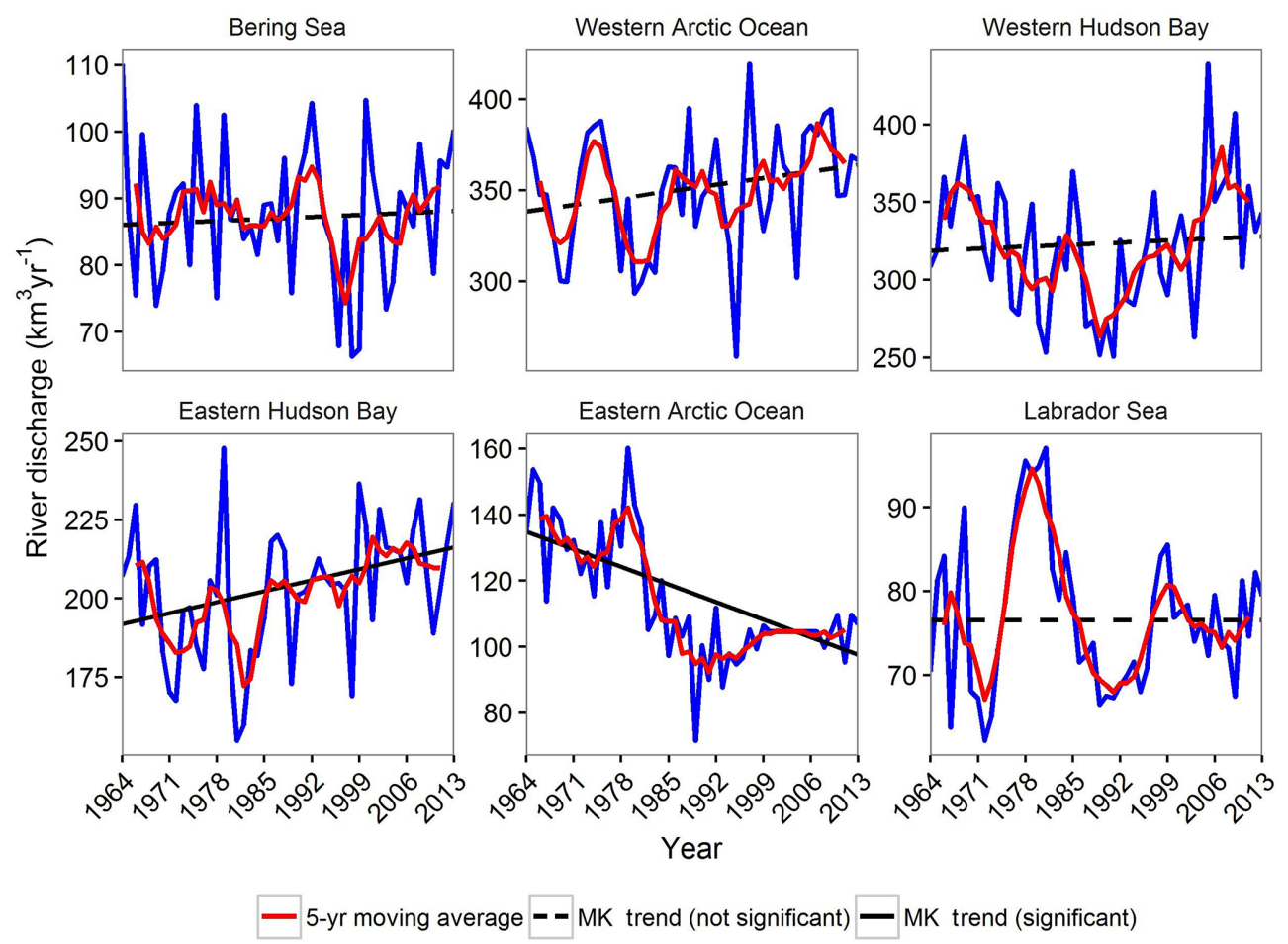

Figure 2. Time series of total annual discharge for six major drainage basins of northern Canada, 1964-2013.

to the eastern Arctic Ocean from 1982 onward arises largely from the inter-basin diversion of the Caniapiscau River to La Grande Rivière, enhancing discharge into the eastern Hudson and James Bay. Discharge to the Labrador Sea shows strong decadal fluctuations that may be associated with climate variability such as different phases of the Arctic Oscillation. For northern Canada as a whole, a modest (but insignificant) positive trend of $0.21 \mathrm{~km}^{3} \mathrm{yr}^{-1} \mathrm{yr}^{-1}$ is found, equivalent to a change of $<1 \%$ in mean annual discharge (Fig. 3). The 5year-running mean shows at least two distinct phases: a declining trend in the first half of the study period followed by increasing discharge until the early 2010 s. Indeed, MKT analyses reveal a significant decline of $102.8 \mathrm{~km}^{3} 25 \mathrm{yr}^{-1}$ for 1964-1988 followed by a significant increase of $208.8 \mathrm{~km}^{3}$ $25 \mathrm{yr}^{-1}$ for 1989-2013. A case for a possible third phase with relatively stable river discharge across northern Canada could also be argued for the central portion of the record (19851995).

Seasonally, spring and summer river discharge to the eastern Hudson and James Bay and the Labrador Sea decline as flows during those seasons are retained in reservoirs and released in winter for hydropower production when demand peaks (Fig. 4). The strong seasonality in flows observed in the 1960 s and early 1970 s in these two regions nearly vanishes in the 2000s, most notably in the eastern Hudson and James Bay region. For the mostly unregulated Bering Strait and western Arctic Ocean drainage basins, strong seasonality in flows persists through the 50-year study period. There is also a modest, statistically significant increase in winter flows to the western Hudson and James Bay and marked declines in spring flows to the eastern Arctic Ocean. Furthermore, high summer flows to the Bering Sea and to the western Hudson and James Bay arise in the 2000s. Changes in seasonality to the western Hudson and James Bay remain less pronounced than those in the eastern Hudson and James Bay owing to the dominant type of regulation (run-of-river) in the Nelson River versus the large storage capacity of reservoirs in the La Grande Rivière system. For the system as a whole, spring and summer flows are nearly equal $\left(\sim 390 \mathrm{~km}^{3} \mathrm{yr}^{-1}\right)$, given the large (natural and artificial) storage capacity, vast areas and high latitudes of the study basins that delay (into summer) the release of snow meltwater to the Arctic Ocean and adjacent northern seas. A significant decline in summer flows, however, appears over the study period, with perhaps the exception of the 1994-2013 decade (Fig. 5). This is compensated by a gradual and significant increase in winter flows as water releases from reservoirs for hydropower production augments in post-construction decades. In contrast, fall river discharge shows no trend between 1964 and 2013. Autocorrelations between time series of seasonal discharge shows that spring/summer $(r=0.41, p<0.05)$, summer/fall $(r=0.60, p<0.05)$ and fall/winter of the following calendar year $(r=0.31, p<0.05)$ are temporally correlated, showing persistence in seasonal flows. Despite this, there are no statistically significant correlations between time series of river 
Table 2. Statistics of gauged and regulated area, mean, standard deviation (SD), coefficient of variation (CV) and trend of annual river discharge for six drainage basins in northern Canada, 1964-2013.

\begin{tabular}{lllllll}
\hline Region & $\begin{array}{l}\text { Gauged area } \\
\left(\mathrm{km}^{2}\right)\end{array}$ & $\begin{array}{l}\text { Regulated } \\
\mathrm{area}(\%)\end{array}$ & $\begin{array}{l}\text { Mean } \\
\left(\mathrm{km}^{3} \mathrm{yr}^{-1}\right)\end{array}$ & $\begin{array}{l}\mathrm{SD} \\
\left(\mathrm{km}^{3} \mathrm{yr}^{-1}\right)\end{array}$ & $\begin{array}{l}\mathrm{CV} \\
\left(\mathrm{km}^{3} 50 \mathrm{yr}^{-1}\right)\end{array}$ \\
\hline Bering Sea & 346900 & 0.0 & 87.8 & 10.0 & 0.11 & 2.1 \\
Western Arctic Ocean & 1998800 & $14.6^{1,2}$ & 349.9 & 32.8 & 0.09 & 26.2 \\
Western Hudson Bay & 2220400 & $63.0^{2}$ & 323.0 & 41.2 & 0.13 & 9.3 \\
Eastern Hudson Bay & 333070 & $55.3^{2}$ & 202.4 & 20.5 & 0.10 & $24.9^{3}$ \\
Eastern Arctic Ocean & 233900 & 36.1 & 114.0 & 18.7 & 0.16 & $-38.1^{3}$ \\
Labrador Sea & 122270 & 75.7 & 77.0 & 8.7 & 0.11 & -0.05 \\
All Regions & 5255340 & $40.9^{2}$ & 1154.1 & 76.1 & 0.07 & 10.5 \\
\hline
\end{tabular}

${ }^{1}$ Covers only area of the Peace River basin, the remainder of the Mackenzie River basin is assumed to be unregulated. ${ }^{2}$ As of 2013.

${ }^{3}$ Statistically significant trends $(p<0.05)$.

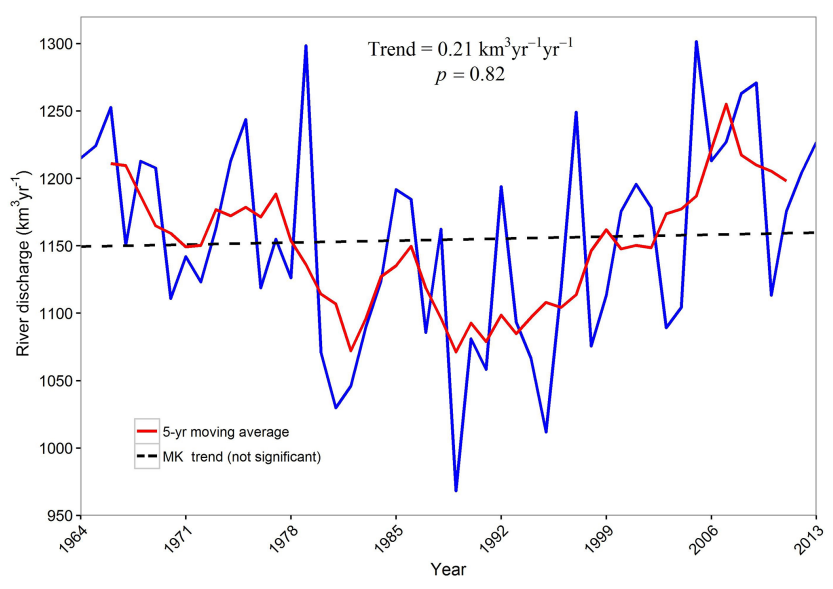

Figure 3. Time series of total annual discharge for 42 rivers draining northern Canada, 1964-2013.

discharge in other seasons, including between spring and fall of a given year.

\subsection{Spatial analyses}

Large, significant trends in the 1964-2013 annual river discharge occur mainly in regulated systems (Fig. 6). A notable exception is the Chesterfield Inlet that shows a $4.9 \mathrm{~km}^{3}$ $50 \mathrm{yr}^{-1}$ increase across the study period, noting however the potential recording issues for this system (see Sect. 3.1). Rivers draining into the eastern Arctic Ocean and Labrador Sea nearly all show declines between 1964 and 2013, in part owing to flow regulation, retention and diversions; nearby unregulated systems also show declines. Couplets of large positive and negative trends to western and eastern Hudson and James Bay arise from diverted flows from one system to another. Otherwise, there are no significant trends in river discharge to the Bering Strait and western Arctic Ocean during the study period. Seasonal analyses reveal a consistent pattern toward greater winter discharge across northern
Canada (with a few exceptions) in both regulated and unregulated systems, with few significant changes during the shoulder seasons apart from the strong positive trends in fall in La Grande Rivière and the Nelson River, and strong (but insignificant) spring discharge increases in the Nelson and Mackenzie rivers (Fig. 7). In contrast, there is a general trend toward less river discharge during summer with the exception of La Grande Rivière and the Nelson River where diversions from nearby systems enhance flows in all seasons. Chesterfield Inlet exhibits a strong positive trend in summer discharge but again, care must be taken in interpreting this result given the changes in recording methodology in the 1980s (see Sect. 3.1).

\subsection{Variability arising from flow regulation and climate}

Impacts of regulation on discharge variability are examined by considering inter-decadal differences in the variability of paired regulated and unregulated rivers (see Sect. 3.2.2). Inter-decadal analysis is used because, in some large systems, there has been a stepped introduction of hydroelectric development over the 5 decades in this study (e.g. Nelson River and La Grande Rivière; see Sect. 2.2). Table 3 presents statistics of inter-decadal variability in discharge for eight major regulated rivers and seven of their unregulated counterparts. Regulated rivers in this table are in bold, and their unregulated counterparts are found in the row that follows. Figure 8 shows box-and-whisker plots of CVs for regulated versus unregulated rivers for each season over the 5 decades. Table S1 in the Supplement provides the inter-decadal variability of all 42 rivers across seasons.

The greatest intra-decadal variability is seen from 1974 to 1983, a period of rapid construction and diversions in most of the regulated rivers (Table 3 and Fig. 8). Flow regulation generally suppresses variability compared to matching unregulated rivers, as has been observed in the Eurasian $\mathrm{Ob}$ and Yenisei rivers (Yang et al., 2004a, b). This effect is the greatest post-construction during winter and to a lesser extent in the fall, presumably to accommodate higher energy 


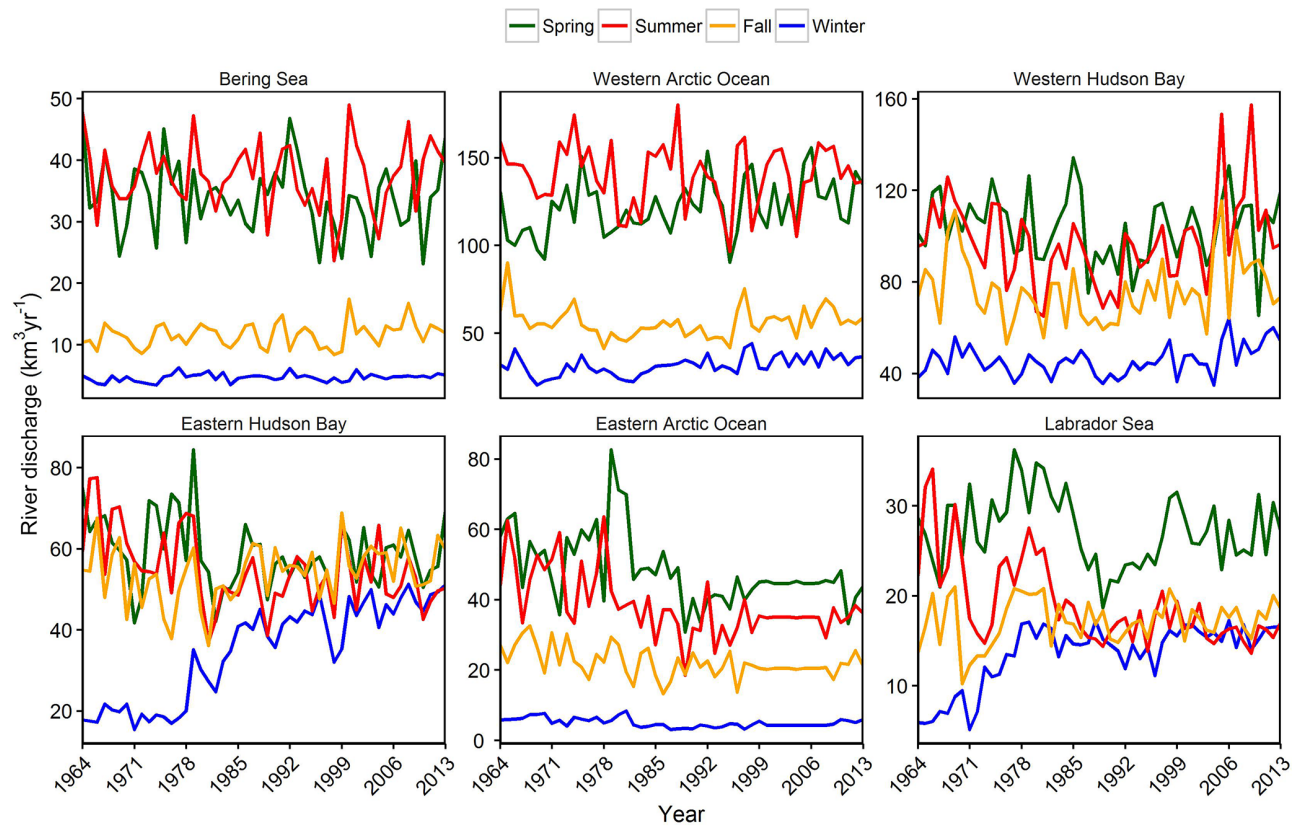

Figure 4. Time series of total seasonal discharge for six major drainage basins of northern Canada, 1964-2013.

Table 3. Paired comparisons of decadal statistics for the mean, standard deviation (SD) and coefficient of variation (CV) of annual river discharge for eight regulated and seven matching unregulated rivers.

\begin{tabular}{|c|c|c|c|c|c|c|c|c|c|c|c|c|c|c|c|}
\hline \multirow[t]{2}{*}{ Rivers* } & \multicolumn{3}{|c|}{$1964-1973$} & \multicolumn{3}{|c|}{ 1974-1983 } & \multicolumn{3}{|c|}{ 1984-1993 } & \multicolumn{3}{|c|}{ 1994-2003 } & \multicolumn{3}{|c|}{ 2004-2013 } \\
\hline & $\begin{array}{l}\text { Mean } \\
\left(\mathrm{km}^{3}\right. \\
\left.\mathrm{yr}^{-1}\right)\end{array}$ & $\begin{array}{l}\mathrm{SD} \\
\left(\mathrm{km}^{3}\right. \\
\left.\mathrm{yr}^{-1}\right)\end{array}$ & $\mathrm{CV}$ & $\begin{array}{l}\text { Mean } \\
\left(\mathrm{km}^{3}\right. \\
\left.\mathrm{yr}^{-1}\right)\end{array}$ & $\begin{array}{l}\mathrm{SD} \\
\left(\mathrm{km}^{3}\right. \\
\left.\mathrm{yr}^{-1}\right)\end{array}$ & $\mathrm{CV}$ & $\begin{array}{l}\text { Mean } \\
\left(\mathrm{km}^{3}\right. \\
\left.\mathrm{yr}^{-1}\right)\end{array}$ & $\begin{array}{l}\mathrm{SD} \\
\left(\mathrm{km}^{3}\right. \\
\left.\mathrm{yr}^{-1}\right)\end{array}$ & $\mathrm{CV}$ & $\begin{array}{l}\text { Mean } \\
\left(\mathrm{km}^{3}\right. \\
\left.\mathrm{yr}^{-1}\right)\end{array}$ & $\begin{array}{l}\mathrm{SD} \\
\left(\mathrm{km}^{3}\right. \\
\left.\mathrm{yr}^{-1}\right)\end{array}$ & $\mathrm{CV}$ & $\begin{array}{l}\text { Mean } \\
\left(\mathrm{km}^{3}\right. \\
\left.\mathrm{yr}^{-1}\right)\end{array}$ & $\begin{array}{l}\mathrm{SD} \\
\left(\mathrm{km}^{3}\right. \\
\left.\mathrm{yr}^{-1}\right)\end{array}$ & $\mathrm{CV}$ \\
\hline Churchill (Manitoba) & 37.00 & 4.20 & 0.11 & 23.70 & 13.49 & 0.57 & 8.43 & 2.93 & 0.35 & 9.59 & 4.40 & 0.46 & 15.76 & 10.50 & 0.67 \\
\hline Nelson & 90.42 & 15.23 & 0.17 & 94.90 & 14.26 & 0.15 & 91.84 & 15.92 & 0.17 & 105.55 & 19.33 & 0.18 & 130.77 & 21.79 & 0.17 \\
\hline Seal & 10.91 & 2.58 & 0.24 & 11.76 & 3.29 & 0.28 & 11.35 & 1.48 & 0.13 & 11.08 & 2.17 & 0.20 & 12.35 & 2.67 & 0.22 \\
\hline Hayes & 21.55 & 2.99 & 0.14 & 20.43 & 3.85 & 0.19 & 16.63 & 5.42 & 0.33 & 18.63 & 4.87 & 0.26 & 21.31 & 6.16 & 0.29 \\
\hline La Grande & 56.81 & 6.93 & 0.12 & 58.77 & 9.62 & 0.16 & 96.11 & 11.37 & 0.12 & 99.50 & 11.36 & 0.11 & 109.89 & 11.51 & 0.10 \\
\hline Grande Rivière de la Baleine & 21.86 & 2.11 & 0.10 & 20.04 & 2.25 & 0.11 & 19.38 & 2.45 & 0.13 & 17.80 & 2.85 & 0.16 & 18.98 & 1.80 & 0.09 \\
\hline Eastmain & 30.01 & 3.72 & 0.12 & 20.62 & 13.12 & 0.64 & 3.17 & 0.34 & 0.11 & 3.11 & 0.39 & 0.13 & 3.62 & 0.06 & 0.02 \\
\hline Rupert & 27.54 & 3.51 & 0.13 & 27.65 & 2.98 & 0.11 & 25.18 & 1.83 & 0.07 & 26.17 & 2.28 & 0.09 & 20.04 & 7.70 & 0.38 \\
\hline Nottaway & 33.11 & 4.71 & 0.14 & 33.49 & 5.31 & 0.16 & 29.93 & 6.84 & 0.23 & 32.97 & 4.54 & 0.14 & 31.84 & 5.20 & 0.16 \\
\hline Koksoak & 74.90 & 8.27 & 0.11 & 66.21 & 12.96 & 0.20 & 45.58 & 7.85 & 0.17 & 44.51 & 2.51 & 0.06 & 46.65 & 2.38 & 0.05 \\
\hline A la Baleine & 17.07 & 2.31 & 0.14 & 16.95 & 1.49 & 0.09 & 14.60 & 2.52 & 0.17 & 15.57 & 1.06 & 0.07 & 15.91 & 1.06 & 0.07 \\
\hline Moose & 42.76 & 6.05 & 0.14 & 39.45 & 7.63 & 0.19 & 38.77 & 6.28 & 0.16 & 35.91 & 4.31 & 0.12 & 38.16 & 10.39 & 0.27 \\
\hline Churchill (Labrador) & 51.56 & 8.39 & 0.16 & 64.63 & 6.79 & 0.10 & 53.44 & 5.39 & 0.10 & 56.02 & 4.14 & 0.07 & 55.78 & 2.84 & 0.05 \\
\hline Eagle & 8.02 & 1.14 & 0.14 & 8.77 & 1.66 & 0.19 & 7.48 & 1.39 & 0.19 & 8.05 & 1.08 & 0.13 & 7.79 & 0.95 & 0.12 \\
\hline
\end{tabular}

* Bold values denote regulated rivers.

demands (1984-2003; Fig. 8). The Churchill River (Manitoba) is a noteworthy exception to this trend, with increases in inter-decadal CV post-diversion $(1984-2013 \mathrm{CV}=0.35-$ 0.67) compared to pre-diversion $(1964-1973 \mathrm{CV}=0.11)$. Much of this increase in variability has occurred during fall and winter over the last 2 decades (1994-2013 CV $=0.94$ 1.16; Table S1) following a period of relatively lower variability from 1984 to 1993.

Interestingly, enhanced variability arises in both regulated and unregulated rivers in the most recent decade (2004-
2013) for all seasons, but most notably during summer (Fig. 8). The unregulated Nottaway River experiences its highest summer variability (by a factor of 2) compared to previous decades $(\mathrm{CV}=0.47)$, and both the regulated Churchill (Manitoba) and Moose rivers experience their greatest flow variability with their matching unregulated rivers experiencing their second greatest flow variability (Table 3). Increasing overall discharge trends reported in this study are likely influenced by increasing mean summer discharge and variability in the most recent decade (2004- 


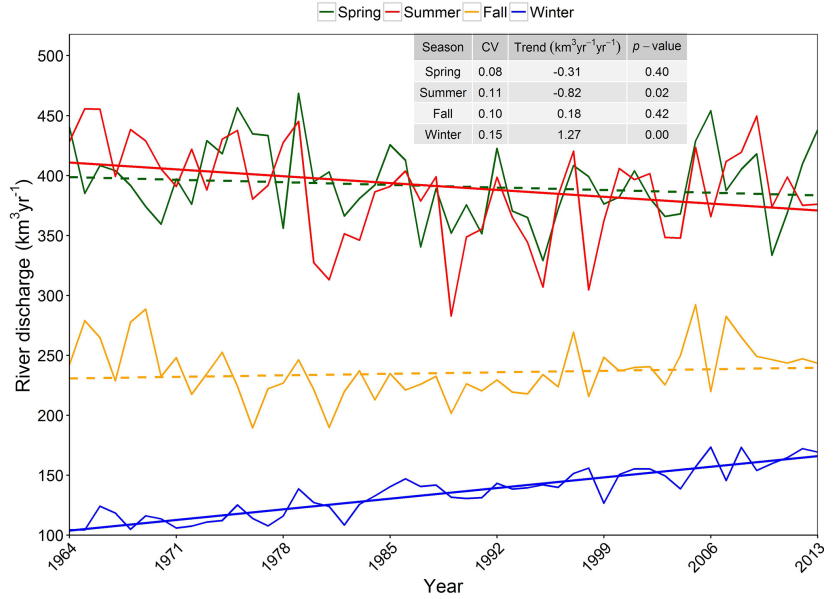

Figure 5. Time series of total seasonal discharge for 42 rivers draining northern Canada, 1964-2013. Thick solid (dashed) lines denote statistically significant (insignificant) trends.

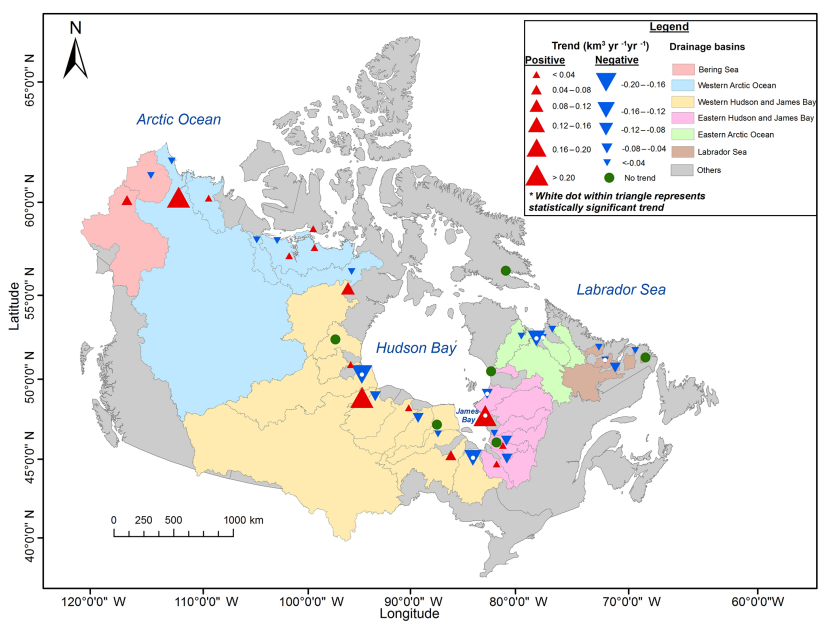

Figure 6. Spatial trend analysis for the annual discharge of 42 rivers of northern Canada, 1964-2013.

2013), which seems to be largely climate driven as it occurs in both regulated and unregulated systems. Particularly in the western Hudson and James Bay region, an increasing number of large summer precipitation and rainfall-runoff events in recent years have, in some cases, yielded annual hydrographs with dual peaks (Ahmari et al., 2016; Blais et al., 2016). Increasing variability may also be influenced by the changing magnitude, timing, frequency and duration of flood events observed in some gauges of our study area (Burn and Whitfield, 2016). Of note is the introduction of regulation on the Rupert River (in 2009) and enhanced variability from 2004 to 2013 not seen otherwise in rivers draining into the eastern Arctic Ocean or Labrador Sea (with the exception of the Alexis River).

\subsection{Climatological hydrographs}

Climatological hydrographs of daily river discharge for each of the six regional drainage basins exhibit relatively consistent patterns characteristic of nival regimes, with low flows in winter, a spring freshet induced by snowmelt, followed by a recession toward lower flows in late summer and fall (Fig. 9). Higher winter flows to western and eastern Hudson and James Bay and the Labrador Sea occur partly because of strong regulation and flow retention in reservoirs during other seasons. Noticeable reductions in streamflow input to the Hudson and James Bay that occur at the start and near the end of the calendar year happen in association with New Year's, Christmas and Boxing days. Reductions in hydropower demand and consumption during these Canadian statutory holidays abruptly decrease flows into Hudson Bay from the highly regulated Nelson, Moose and La Grande Rivière systems.

\section{Discussion}

\subsection{Comparison with other studies}

Milliman and Farnsworth (2011) provided a comprehensive table of mean annual discharge for most rivers included in this study. Results herein are generally consistent with the mean annual discharge from Milliman and Farnsworth (2011) with variations likely dependent on the selected study period and basin area under consideration. Exceptions arise in some rivers, most notably for Nunavut's Coppermine River where Milliman and Farnsworth (2011) reported a mean annual discharge of 11 and $2.6 \mathrm{~km}^{3} \mathrm{yr}^{-1}$ before and after regulation, respectively. Results from this study yield a mean annual discharge of $8.8 \mathrm{~km}^{3} \mathrm{yr}^{-1}$ for the Coppermine River - with no known flow regulation over 19642013 according to the Water Survey of Canada. Milliman and Farnsworth (2011) also reported mean annual discharge rates of $23 \mathrm{~km}^{3} \mathrm{yr}^{-1}$ and $15 \mathrm{~km}^{3} \mathrm{yr}^{-1}$ before and after regulation, respectively, for northern Ontario's Severn River (despite this system being unregulated), with our results indicating mean annual discharge of $21.9 \mathrm{~km}^{3} \mathrm{yr}^{-1}$. The present study also reports underestimates of $\sim 7-13 \mathrm{~km}^{3} \mathrm{yr}^{-1}$ for the Albany, Attawapiskat and Winisk rivers of northern Ontario compared to Milliman and Farnsworth (2011), perhaps owing to different study periods and/or basin areas under consideration. Discrepancies in mean annual discharge for La Grande Rivière, the Eastmain and Rupert rivers are likely due to recent water management practices to enhance power production at the James Bay hydroelectric complex. Statistics reported in this study are based on hydrometric data provided directly by Hydro-Québec (post development of hydropower facilities and infrastructure) that better reflect the current level of regulation in these systems. 

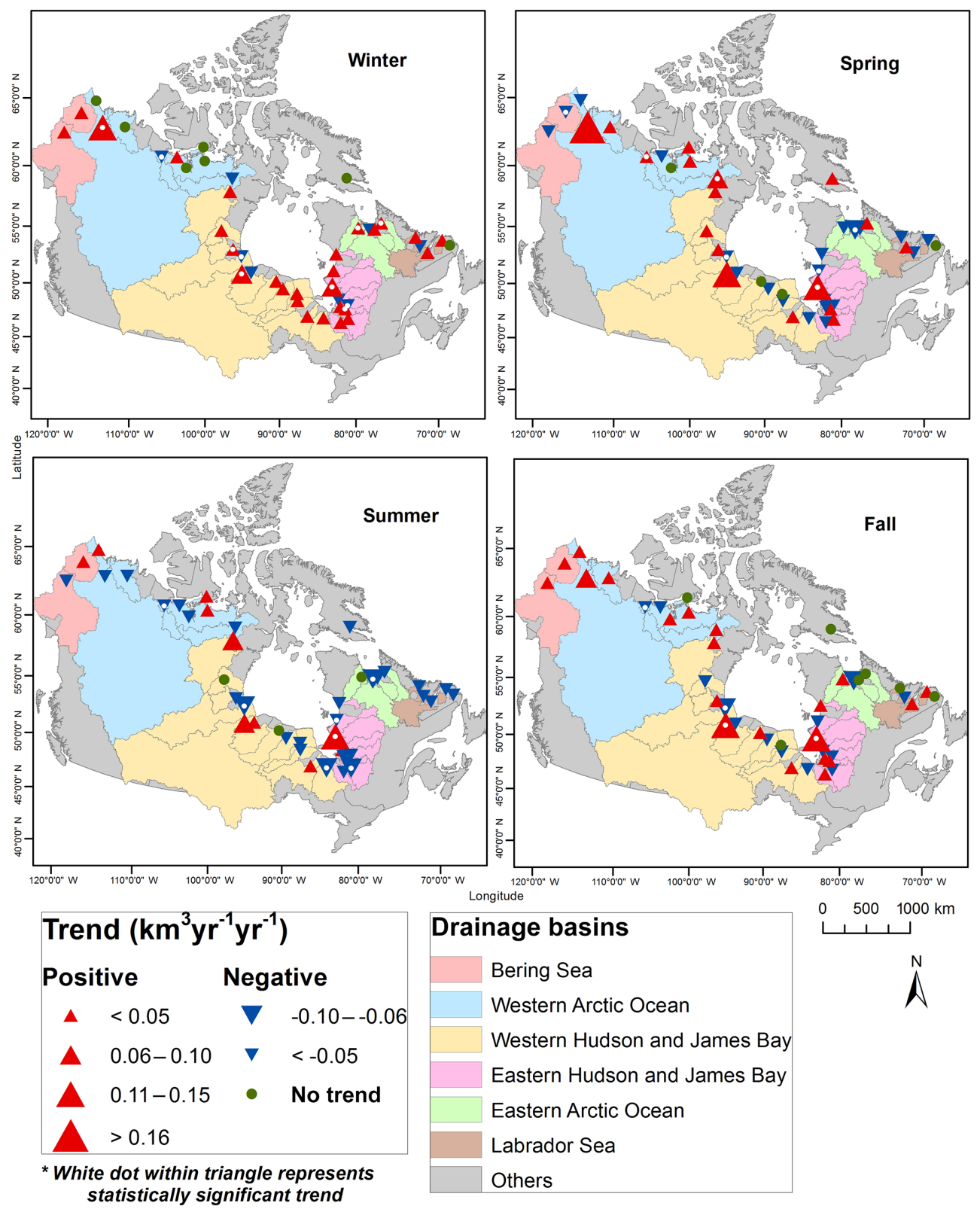

Bering Sea

Western Arctic Ocean

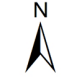

Figure 7. Spatial trend analysis for the seasonal discharge of 42 rivers of northern Canada, 1964-2013.

Benke and Cushing (2005) provided mean annual streamflow statistics for 11 rivers examined in this study (i.e. the Porcupine, Yukon, Chesterfield Inlet, Seal, La Grande, Koksoak, Mackenzie, Moose, Nelson and Churchill (both in Manitoba and Labrador) rivers). Our results are generally consistent with Benke and Cushing (2005) with two notable exceptions. First, mean annual discharge for the Mackenzie River is $\sim 27 \mathrm{~km}^{3} \mathrm{yr}^{-1}$ greater in this study, perhaps due to the exclusion of the Peel River's contribution to overall Mackenzie River discharge by Benke and Cushing (2005). Second, Benke and Cushing (2005) reported a mean annual discharge of $\sim 200 \mathrm{~km}^{3} \mathrm{yr}^{-1}$ for the Yukon River, although this considers both the Canadian and American contributing area (total of $839200 \mathrm{~km}^{2}$ ), rather than just the upstream part in Canada examined here (gauged area $=288000 \mathrm{~km}^{2}$ ). Discrepancies also arise for the Koksoak River and La Grande Rivière as mean annual discharge values reported by Benke and Cushing (2005) reflected conditions prior to the diversion of the upper Caniapiscau River to the La Grande Rivière system.

While Déry and Wood (2005) first reported a $10 \%$ decline in river discharge across northern Canada from 1964 to 2003, this effort finds a remarkable reversal to that trend in expanding the study period by only a decade. In the sec- 

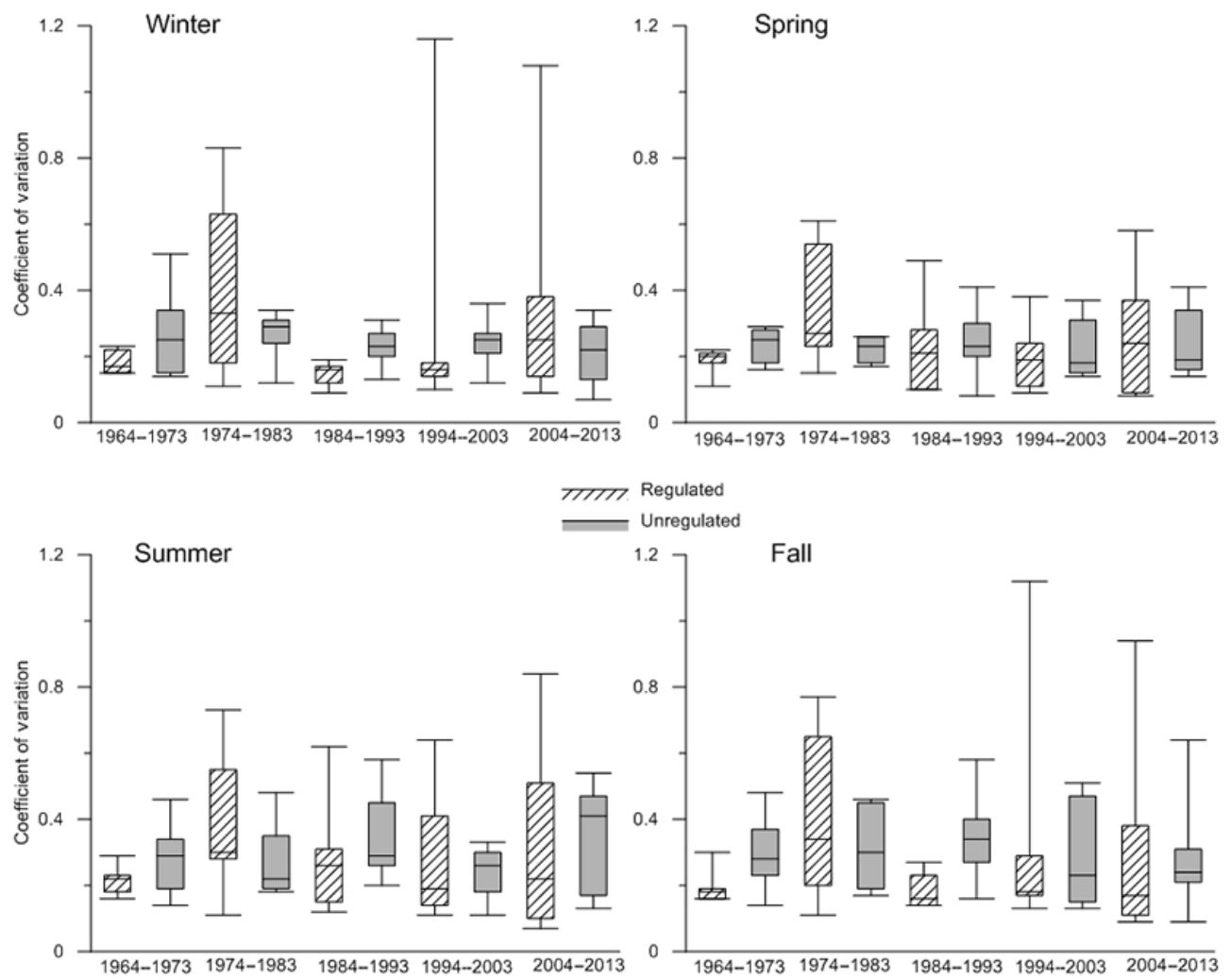

Figure 8. Box-and-whisker plots of the coefficient of variation of seasonal river discharge for eight regulated and seven "matching" unregulated rivers for 5 decades over 1964-2013. Boxes indicate the 25th and 75th inter-quantile ranges with the central horizontal lines denoting the median values, while the whiskers represent the 5 th and 95 th percentiles in the data.

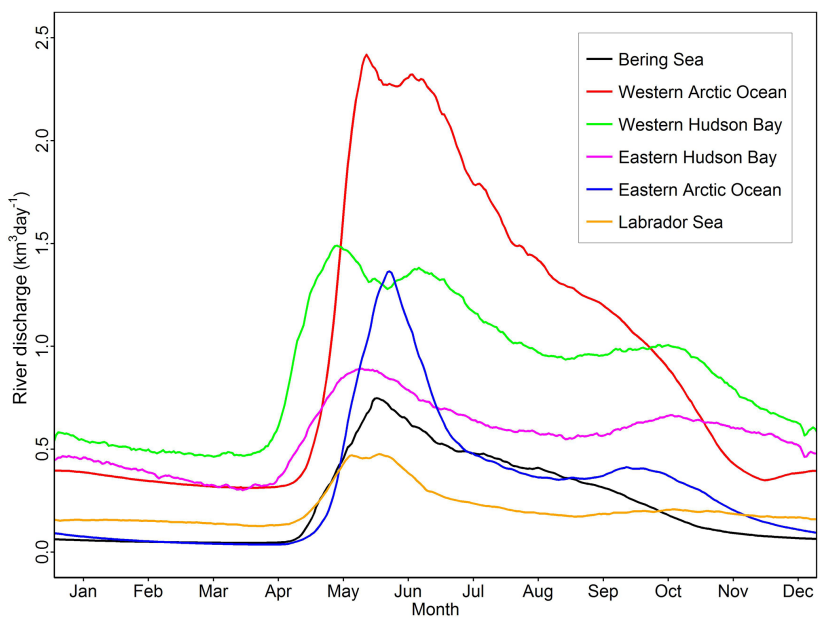

Figure 9. Climatological hydrographs of daily mean river discharge for six major drainage basins of northern Canada, 1964-2013.

ond half of the study period, river discharge in northern Canada increased by $18.1 \%$ (relative to its overall mean annual discharge). This is in stark contrast to the first half of the study period during which river discharge declined significantly. Rood et al. (2016) also documented a statis- tically significant $(p<0.05) \sim 1.5 \%$ decade $^{-1}$ increase in Mackenzie River discharge over 1939-2013, consistent with the pattern observed in this study; however, our abbreviated study period reveals an insignificant trend in this system (Table 1). St. Jacques and Sauchyn (2009) likewise reported significant increases in winter (base) flows for the Mackenzie and other rivers of the Northwest Territories in possible response to permafrost degradation. These findings suggest that rivers in northern Canada are now responding similarly to rising air temperatures as those in Eurasia (Peterson et al., 2002), in accord with climate change projections (Milly et al., 2005; van Vliet et al., 2013). In fact, the rate of increase of $8.4 \mathrm{~km}^{3} \mathrm{yr}^{-1} \mathrm{yr}^{-1}$ for river discharge across northern Canada from 1989 to 2013 exceeds the overall trend of $6.3 \mathrm{~km}^{3} \mathrm{yr}^{-1} \mathrm{yr}^{-1}$ for 16 Eurasian rivers draining into the Arctic Ocean from 1964 to 2000 (McClelland et al., 2006). The period of record remains relatively short and care must be taken in interpreting these findings; nonetheless, attempts should be made to reconcile observed trends in northern Canada and Eurasia using identical study periods and methodologies. Decadal climate variability associated with the Arctic, Pacific Decadal, and Atlantic Multidecadal oscillations, among other large-scale modes of climate variability, are known to affect river discharge in northern Canada 
(Déry and Wood, 2004; Kingston et al., 2006; Assani et al., 2010; Rood et al., 2016). We stress that it remains important to continue monitoring river discharge in northern Canada (and expand where possible to attain WMO standards) as this region is expected to continue warming rapidly in the twentyfirst century (Coulibaly et al., 2013; Gough and Wolfe, 2001; Gagnon and Gough, 2005).

\subsection{Anthropogenic influences}

While rising air temperatures and changing precipitation patterns are key factors in altering northern Canadian river discharge, another control remains anthropogenic activities such as water retention, regulation and diversion. The development of large hydroelectric complexes in northern Québec, Ontario, Manitoba and across the Canadian Prairies into BC has significantly altered the seasonality of flows in northern Canada, most notably to western and eastern Hudson and James Bay. River diversions and flow regulation typically do not influence overall flow volumes to the coastal ocean (McClelland et al., 2006); however, pronounced changes in seasonality accompany regulation, especially in systems with large storage capacity such as the Mackenzie (Peace) River and La Grande Rivière. Furthermore, short-term (i.e. 1-5 years) declines in river discharge to the coastal ocean can arise from the filling of large reservoirs for hydropower production. Across northern Canada, $>300 \mathrm{~km}^{3}$ of water storage capacity has been developed since 1964 (Lee et al., 2012). This may lead to both a short-term decline in observed flows to the coastal ocean while reservoirs are filled, and "aging" of water in storage affecting its properties, such as biochemistry and temperature, while enhancing evaporative losses (Vörösmarty and Sahagian, 2000). Perhaps lesser known are the impacts of land cover and land use change on river discharge in northern Canada. Deforestation through wood harvesting depresses water demand by vegetation while increasing soil moisture and runoff generation (Boon, 2012). In contrast, the intensification of agricultural activities, particularly in the Canadian Prairies, increases water demand for irrigation. Anthropogenic activities play a major role in changing pan-Arctic hydrology that requires special attention when assessing observed changes. Thus, the use of land surface or hydrological models is particularly useful in identifying the individual roles of climate change and anthropogenic activities on streamflow variability and trends that otherwise may be masked in the observational data.

\subsection{Physical impacts to the marine environment}

Changes in seasonal river conditions induced by climate change and river regulation affect the physical regime of coastal estuaries by modifying salinity levels and the input of nutrients and sediments (Gillanders et al., 2011). For instance, the Eastmain River estuary experienced an increase in salinity after diversion into the La Grande Rivière sys- tem (Messier et al., 1986; Drinkwater and Frank, 1994), concurrently lowering salinity in La Grande Rivière's estuary during winter (Whittaker, 2006). Increasing river discharge in northern Canada strengthens ocean stratification, thereby suppressing deep-water formation in the Labrador Sea (Myers, 2005). This, in turn, weakens the thermohaline circulation that is responsible for the transport of heat and nutrients in the North Atlantic Ocean (Ogi et al., 2001; Rennermalm et al., 2007). Increasing winter discharge in northern Canada also delivers sensible heat to the coastal ocean, promoting the ablation of sea ice in estuaries and delta regions (Kuzyk et al., 2008; Searcy et al., 1996). This emphasises the need for basin-scale numerical modelling of the coupling between freshwater fluxes and the marine environment (e.g. Saucier et al., 2004).

\section{Conclusion}

This study provides an update on the recent variability and trends in river discharge across northern Canada. In contrast to previous studies (e.g. Déry and Wood, 2005; McClelland et al., 2006), we have reported a strong increasing trend in river discharge in northern Canada since the 1990s. Between 1989 and 2013, total annual river discharge in northern Canada increased by $208.8 \mathrm{~km}^{3} 25 \mathrm{yr}^{-1}$, equivalent to an $18.1 \%$ rise relative to mean annual discharge over the study period. This aligns with recent trends in Eurasia associated with increased moisture transport to high northern latitudes (Zhang et al., 2013; Rawlins et al., 2009). The recent tendency towards a negative phase of the Arctic Oscillation, perhaps associated with declining Arctic sea ice, is likely contributing to increasing river discharge in northern Canada (Déry and Wood, 2004; Screen et al., 2013). The positive phase of the Arctic Oscillation advects cold, dry air over north-eastern Canada, reducing snowfall amounts and river discharge (Déry and Wood, 2004; Déry et al., 2005b). Thus, warming air temperatures and reductions in Arctic sea ice extent result in more abundant precipitation across northern Canada that yield higher discharge rates to the Arctic Ocean and adjacent northern seas. An avenue for future work will therefore be spectral and/or wavelet analysis of river discharge records in northern Canada for comparison with climate variability associated with large-scale teleconnections, such as the Arctic, Pacific Decadal and Atlantic Multidecadal oscillations. Isolating the impacts of large-scale climate variability on river discharge through such methods would facilitate more robust detection of linear trends in the hydrological records associated with climate warming, among other factors.

Flow regulation is shown to suppress natural discharge variability, particularly during winter. This effect is distinguishable in flow records following the period of intensive construction of hydroelectric facilities in northern Canada (mid-1970s to early 1980s). Of note is the augmented vari- 
ability in both regulated and unregulated rivers during the most recent decade of study (2004-2013), which may be climate driven. Climate change and anthropogenic activities influence not only the annual amounts and inter-annual/interdecadal variability of river discharge into the Arctic Ocean and polar seas but also its timing and day-to-day variability. Thus, another prospective avenue for research consists of a detailed examination of temporal changes in the climatological hydrographs in both regulated and unregulated rivers.

Since the approach used in this study relies on the existence of observed hydrometric data, there are temporal and spatial gaps in our data set and analyses, most notably in the high Arctic and CAA (Fig. 1). Temporal gaps are infilled using a two-step approach that includes use of daily climatological values of streamflow when data from upstream gauges remain unavailable, with the caveat of possibly reducing the magnitude and significance of monotonic trends. A future effort will therefore refine this strategy by considering linear interpolation for short ( $\leq 1$ week) temporal gaps and cross-correlations or the maintenance of variance method (MOVE) by Hirsch (1982) based on proximal rivers for longer ( $>1$ week) periods of missing data (HernándezHenríquez et al., 2010), among other methods. An additional approach to infill both temporal and spatial gaps consists of hydrological modelling combined with meteorological forcing from observational, reanalysis or modelling data sets. Use of a hydrological model forced by output from global climate models under various scenarios also allows for projections of future discharge across northern Canada. This work is currently being undertaken by the authors with the ArcticHYPE hydrological model (Andersson et al., 2015) for the Hudson and James Bay drainage basin under existing flow regulation practices.

\section{Data availability}

The time series of river discharge and trend analyses are currently available by contacting the corresponding author. These time series are not available through a data repository but will be made accessible online through a web portal.
Note, however, data for the Nelson River and La Grande Rivière remain the proprietary right of the data owners, Manitoba Hydro and Hydro-Québec, respectively. These data cannot be shared with other researchers without their explicit consent. We have signed agreements to that effect through our project entitled "BaySys".

All other data used in the present study are from the Water Survey of Canada and the Direction d'Expertise Hydrique du Québec, and can be accessed publicly online.

\section{The Supplement related to this article is available online at doi:10.5194/hess-20-4801-2016-supplement.}

Acknowledgements. Thanks to the Water Survey of Canada, Manitoba Hydro, Hydro-Québec, and the Direction d'Expertise Hydrique du Québec for access to hydrometric data and the Natural Sciences and Engineering Research Council of Canada, Manitoba Hydro, and partners through funding of the BaySys project. Thanks to Marco Hernández-Henríquez (UNBC) for assistance in figure preparation for the poster that preceded this manuscript, Shane Wruth (Manitoba Hydro) and Catherine Guay, Samer Alghabra and Jonathan Guidi (Hydro-Québec) for compiling data for the Nelson River and La Grande Rivière, respectively, Kristina Koenig and colleagues at Manitoba Hydro for logistical support and review of the paper, to two anonymous referees for their constructive comments that led to an improved paper, and to Eric F. Wood (Princeton University) for motivating this effort and ongoing support of this research.

Edited by: D. Lettenmaier

Reviewed by: two anonymous referees 


\section{References}

Ahmari, H., Blais, E.-L., and Greshuk, J.: The 2014 flood event in the Assiniboine River Basin: causes, assessment and damage, Can. Water Resour. J., 41, 85-93, doi:10.1080/07011784.2015.1070695, 2016.

Andersson, J. C. M., Pechlivanidis, I. G., Gustafsson, D., Donnelly, C., and Arheimer, B.: Key factors for improving large-scale hydrological model performance, European Water, 49, 77-88, 2015

Assani, A. A., Landais, D., Mesfoui, M., and Matteau, M.: Relationship between the Atlantic Multidecadal Oscillation index and variability of mean annual flows for catchments in the St. Lawrence watershed (Québec, Canada) during the past century, Hydrol. Res., 4, 115-125, 2010.

Benke, A. C. and Cushing, C. E. (Eds): Rivers of North America, Elsevier Academic, 1144 pp., 2005.

Blais, E.-L., Greshuk, J., and Stadnyk, T.: The 2011 flood event in the Assiniboine River Basin: causes, assessment and damages, Can. Water Resour. J., 41, 74-84, doi:10.1080/07011784.2015.1046139, 2016.

Boon, S.: Snow accumulation following forest disturbance, Ecohydrology, 5, 279-285, 2012.

Burn, D. H. and Whitfield, P. H.: Changes in floods and flood regimes in Canada, Can. Water Resour. J., 41, 139-150, doi:10.1080/07011784.2015.1026844, 2016.

Callaghan, T. V., Johansson, M., Brown, R. D., Groisman, P. Ya., Labba, N., Radionov, V., Bradley, R. S., Blangy, S., Bulygina, O. N., Christensen, T. R., Colman, J. E., Essery, R. L. H., Forbes, B. C., Forchhammer, M. C., Golubev, V. N., Honrath, R. E., Juday, G. P., Meshcherskaya, A. V., Phoenix, G. K., Pomeroy, J., Rautio, A., Robinson, D. A., Schmidt, N. M., Serreze, M. C., Shevchenko, V. P., Shiklomanov, A. I., Shmakin, A. B., Sköld, P., Sturm, M., Woo, M.-K., and Wood, E. F.: Multiple effects of changes in Arctic snow cover, Ambio, 40, 32-45, 2011.

Coulibaly, P., Samuel, J., Pietroniro, A., and Harvey, D.: Evaluation of Canadian National Hydrometric Network density based on WMO 2008 standards, Can. Water Resour. J., 38, 159-167, 2013.

Déry, S. J. and Brown, R. D.: Recent Northern Hemisphere snow cover extent trends and implications for the snow-albedo feedback, Geophys. Res. Lett., 34, L22504, doi:10.1029/2007GL031474, 2007.

Déry, S. J. and Wood, E. F.: Teleconnection between the Arctic Oscillation and Hudson Bay river discharge, Geophys. Res. Lett., 31, L18205, doi:10.1029/2004GL020729, 2004.

Déry, S. J. and Wood, E. F.: Decreasing river discharge in northern Canada, Geophys. Res. Lett., 32, L10401, doi:10.1029/2005GL022845, 2005.

Déry, S. J., Stieglitz, M., McKenna, E. C., and Wood, E. F.: Characteristics and trends of river discharge into Hudson, James, and Ungava Bays, 1964-2000, J. Climate, 18, 2540-2557, 2005 a.

Déry, S. J., Sheffield, J., and Wood, E. F.: Connectivity between Eurasian snow cover extent and Canadian snow water equivalent and river discharge, J. Geophys. Res., 110, D23106, doi:10.1029/2005JD006173, 2005b.

Déry, S. J., Hernández-Henríquez, M. A., Burford, J. E., and Wood, E. F.: Observational evidence of an intensifying hydrological cycle in northern Canada, Geophys. Res. Lett., 36, L13402, doi:10.1029/2009GL038852, 2009.
Déry, S. J., Mlynowski, T. J., Hernández-Henríquez, M. A., and Straneo, F.: Interannual variability and interdecadal trends in Hudson Bay streamflow, J. Marine Syst., 88, 341-351, 2011.

Di Baldassarre, G. and Montanari, A.: Uncertainty in river discharge observations: a quantitative analysis, Hydrol. Earth Syst. Sci., 13, 913-921, doi:10.5194/hess-13-913-2009, 2009.

Drinkwater, K. F. and Frank, K. T.: Effects of river regulation and diversion on marine fish and invertebrates, Aquat. Conserv., 4 , 135-151, 1994.

Dynesius, M. and Nilsson, C.: Fragmentation and flow regulation of river systems in the northern third of the world, Science, 266 , 753-762, 1994.

Francis, J. A. and Vavrus, S. J.: Evidence linking Arctic amplification to extreme weather in mid-latitudes, Geophys. Res. Lett., 39, L06801, doi:10.1029/2012GL051000, 2012.

Gagnon, A. S. and Gough, W. A.: Climate change scenarios for the Hudson Bay region: An intermodel comparison, Climatic Change, 69, 269-297, 2005.

Gardner, A. S., Moholdt, G., Wouters, B., Wolken, G. J., Burgess, D. O., Sharp, M. J., Cogley, G. J., Braun, C., and Labine, C.: Sharp acceleration of mass loss from Canadian Arctic Archipelago glaciers and ice caps, Nature, 473, 357-360, 2011.

Gillanders, B. M., Elsdon, T. S., Halliday, I. A., Jenkins, G. P., Robins, J. B., and Valesini, F. J.: Potential effects of climate change on Australian estuaries and fish utilising estuaries: A review, Mar. Freshwater Res., 62, 1115-1131, 2011.

Gough, W. A. and Wolfe, E.: Climate change scenarios for Hudson Bay, Canada, from general circulation models, Arctic, 54, 142 148, 2001.

Hernández-Henríquez, M. A., Mlynowski, T. J., and Déry, S. J.: Reconstructing the natural streamflow of a regulated river: A case study of La Grande Rivière, Québec, Canada, Can. Water Resour. J., 35, 301-316, 2010.

Hernández-Henríquez, M. A., Déry, S. J., and Derksen, C.: Polar amplification and elevation-dependence in trends of Northern Hemisphere snow cover extent, 1971-2014, Environ. Res. Lett., 10, 044010, doi:10.1088/1748-9326/10/4/044010, 2015.

Hinzman, L. D., Bettez, N. D., Bolton, W. R., Chapin, F. S., Dyurgerov, M. B., Fastie, C. L., Griffith, B., Hollister, R. D., Hope, A., Huntington, H. P., Jensen, A. M., Jia, G. J., Jorgenson, T., Kane, D. L., Klein, D. R., Kofinas, G., Lynch, A. H., Lloyd, A. H., McGuire, D., Nelson, F. E., Oechel, W. C., Osterkamp, T. E., Racine, C. H., Romanovsky, V. E., Stone, R. S., Stow, D. A., Sturm, M., Tweedie, C. E., Vourlitis, G. L., Walker, M. D., Walker, D. A., Webber, P. J., Welker, J. M., Winker, K. S., and Yoshikawa, K.: Evidence and implications of recent climate change in northern Alaska and other Arctic regions, Climatic Change, 72, 251-298, 2005.

Hirsch, R. M.: A comparison of four streamflow record extension techniques, Water Resour. Res., 18, 1081-1088, 1982.

Hydro-Québec: Eastmain-1-A and Sarcelle Powerhouses and $\mathrm{Ru}-$ pert Diversion: A hydroelectric project for present and future generations (unpublished report), 28 pp., 2008.

Kendall, M. G.: Rank Correlation Methods, Oxford University Press, New York, 202 pp., 1975.

Kingston, D. G., Lawler, D. M., and McGregor, G. R.: Linkages between atmospheric circulation, climate and streamflow in the northern North Atlantic: Research prospects, Prog. Phys. Geog., 30, 143-174, 2006. 
Kuzyk, Z. A., Macdonald, R. W., Granskog, M. A., Scharien, R. K., Galley, R. J., Michel, C., Barber, D., and Stern, G.: Sea ice, hydrological, and biological processes in the Churchill River estuary region, Hudson Bay, Estuar. Coast. Shelf Sci., 77, 369-384, 2008.

Lammers, R. B., Shiklomanov, A. I., Vörösmarty, C. J., Fekete, B. M., and Peterson, B. J.: Assessment of contemporary Arctic river runoff based on observational discharge records, J. Geophys. Res., 106, 3321-3334, 2001.

Lee, P. G., Hanneman, M., and Cheng, R.: Hydropower Developments in Canada: Number, Size and Jurisdictional and Ecological Distribution, Edmonton, Alberta: Global Forest Watch Canada, 2012 Year of Sustainable Energy for All \#2, 64 pp., 2012.

Lehner, B., Reidy Liermann, C., Revenga, C., Vörösmarty, C., Fekete, B., Crouzet, P., Döll, P., Endejan, M., Frenken, K., Magome, J., Nilsson, C., Robertson, J. C., Rodel, R., Sindorf, N., and Wisser, D.: Global Reservoir and Dam Database, Version 1 (GRanDv1): Dams, Revision 01. Palisades, NY: NASA Socioeconomic Data and Applications Center (SEDAC), doi:10.7927/H4N877QK, 2011.

Liu, J., Curry, J. A., Wang, H., Song, M., and Horton, R. M.: Impact of declining Arctic sea ice on winter snowfall, P. Natl. Acad. Sci. USA, 109, 4074-4079, 2012.

Manitoba Hydro: A history of electric power in Manitoba, Winnipeg, Canada, 76 pp., 1998.

Mann, H. B.: Non-parametric test against trend, Econometrika, 13, 245-259, 1945.

Marshall, S. J., White, E. C., Demuth, M. N., Bolch, T., Wheate, R., Menounos, B., Beedle, M. J., and Shea, J. M.: Glacier water resources on the eastern slopes of the Canadian Rocky Mountains, Can. Water Resour. J., 36, 109-134, 2011.

McClelland, J. W., Holmes, R. M., Peterson, B. J., and Stieglitz, M.: Increasing river discharge in the Eurasian Arctic: Consideration of dams, permafrost thaw, and fires as potential agents of change, J. Geophys. Res., 109, D18102, doi:10.1029/2004JD004583, 2004

McClelland, J. W., Déry, S. J., Peterson, B. J., Holmes, R. M., and Wood, E. F.: A pan-Arctic evaluation of changes in river discharge during the latter half of the 20th century, Geophys. Res. Lett., 33, L06715, doi:10.1029/2006GL025753, 2006.

McKay, G. A. and Gray, D. M.: The distribution of snowcover, in: Handbook of Snow, edited by: Gray, D. M. and Male, D. H., Pergamon Press, Oxford, 153-190, 1981.

Messier, D., Ingram, R. G., and Roy, D.: Physical and biological modifications in response to La Grande hydroelectric complex, in: Canadian Inland Seas, edited by: Martini, I. P., Elsevier, 403424, 1986

Milliman, J. D. and Farnsworth, K. L.: River Discharge to the Coastal Ocean - A Global Synthesis, Cambridge University Press, 384 pp., 2011.

Milly, P. C. D., Dunne, K. A., and Vecchia, A. V.: Global pattern of trends in streamflow and water availability in a changing climate, Nature, 438, 347-350, 2005.

Mlynowski, T. J., Hernández-Henríquez, M. A., and Déry, S. J.: An evaluation of hydrometric monitoring across the Canadian panArctic region, 1950-2008, Hydrol. Res., 42, 479-490, 2011.

Myers, P. G.: Impact of freshwater from the Canadian Arctic Archipelago on Labrador Sea Water formation, Geophys. Res. Lett., 32, L06605, doi:10.1029/2004GL022082, 2005.
Newbury, R. W., McCullough, G. K., and Hecky, R. E.: The Southern Indian Lake impoundment and Churchill River diversion, Can. J. Fish. Aquat. Sci., 41, 548-557, 1984.

Ogi, M., Tachibana, Y., Nishio, F., and Danchenkov, M. A.: Does the fresh water supply from the Amur River flowing into the Sea of Okhotsk affect sea ice formation?, J. Meteorol. Soc. Jpn., 79, 123-129, 2001.

Pelletier, P. M.: Uncertainties in the single determination of river discharge: a literature review, Can. J. Civil. Eng., 15, 834-850, 1988.

Peters, D. L. and Prowse, T. D.: Regulation effects on the lower Peace River, Canada, Hydrol. Process., 15, 3181-3194, 2001.

Peterson, B. J., Holmes, R. M., McClelland, J. W., Vörösmarty C. J., Lammers, R. B., Shiklomanov, A. I., Shiklomanov, I. A., and Rahmstorf, S.: Increasing river discharge to the Arctic Ocean, Science, 298, 2171-2173, 2002.

Rasouli, K., Hernández-Henríquez, M. A., and Déry, S. J.: Streamflow input to Lake Athabasca, Canada, Hydrol. Earth Syst. Sci., 17, 1681-1691, doi:10.5194/hess-17-1681-2013, 2013.

Rawlins, M. A., Serreze, M. C., Schroeder, R., Zhang, X., and McDonald, K. C.: Diagnosis of the record discharge of Arcticdraining Eurasian rivers in 2007, Environ. Res. Lett., 4, 045011, doi:10.1088/1748-9326/4/4/045011, 2009.

Rawlins, M. A., Steele, M., Holland, M. M., Adam, J. C., Cherry, J. E., Francis, J. A., Groisman, P. Ya., Hinzman, L. D., Huntington, T. G., Kane, D. L., Kimball, J. S., Kwok, R., Lammers, R. B., Lee, C. M., Lettenmaier, D. P., McDonald, K. C., Podest, E., Pundsack, J. W., Rudels, B., Serreze, M. C., Shiklomanov, A., Skageth, O., Troy, T. J., Vörösmarty, C. J., Wesnahan, M., Wood, E. F., Woodgate, R., Yang, D., Zhang, K., and Zhang, T.: Analysis of the Arctic system for freshwater cycle intensification: Observations and expectations, J. Climate, 23, 5715-5737, 2010.

Rennermalm, A. K., Wood, E. F., Weaver, A. J., Eby, M., and Déry, S. J.: Relative sensitivity of the Atlantic meridional overturning circulation to river discharge into Hudson Bay and the Arctic Ocean, J. Geophys. Res., 112, G04S48, doi:10.1029/2006JG000330, 2007.

Rood, S. B., Kaluthota, S., Philipsen, L. J., Rood, N. J., and Zanewich, K. P.: Increasing river discharge from the Mackenzie river system to the Arctic Ocean, Hydrol. Process., doi:10.1002/hyp.10986, in press, 2016.

Roy, D. and Messier, D.: A review of the effects of water transfers in the La Grande Hydroelectric Complex (Québec, Canada), River Res. Appl., 4, 299-316, 1989.

Saucier, F., Senneville, S., Prinsenberg, S., Roy, F., Smith, G., Gachon, P., Caya, D., and Laprise, R.: Modelling the sea ice-ocean seasonal cycle in Hudson Bay and Hudson Strait, Canada, Clim. Dynam., 23, 303-326, 2004.

Screen, J. A., Simmonds, I., Deser, C., and Tomas, R.: The atmospheric response to three decades of observed Arctic sea ice loss, J. Climate, 26, 1230-1248, 2013.

Searcy, C., Dean, K., and Stringer, W.: A river-coastal sea ice interaction model: Mackenzie River Delta, J. Geophys. Res., 101, 8885-8894, 1996.

Serreze, M. C., Walsh, J. E., Chapin III, F. S.,, Osterkamp, T., Dyurgerov, M., Romanovsky, V., Oechel, W. C., Morison, J., Zhang, T., and Barry, R. G.: Observational evidence of re- 
cent change in the northern high latitude environment, Climatic Change, 46, 159-207, 2000.

Serreze, M. C., Holland, M. M., and Stroeve, J.: Perspectives on the Arctic's shrinking sea-ice cover, Science, 315, 1533-1536, 2007.

Shi, X., Groisman, P. Ya., Déry, S. J., and Lettenmaier, D. P.: The role of surface energy fluxes in pan-Arctic snow cover changes, Environ. Res. Lett., 6, 035204, doi:10.1088/17489326/6/3/035204, 2011.

Shiklomanov, A. I., Yakovleva, T. J., Lammers, R. B., Karasev, I. P., Vörösmarty, C. J., and Linder, E.: Cold region river discharge uncertainty - estimates from large Russian rivers, J. Hydrol., 326, 231-256, 2006.

Spence, C. and Burke, A.: Estimates of Canadian Arctic Archipelago runoff from observed hydrometric data, J. Hydrol., 362, 247-259, doi:10.1016/j.jhydrol.2008.08.019, 2008.

St. Jacques, J.-M. and Sauchyn, D. J.: Increasing winter baseflow and mean annual streamflow from possible permafrost thawing in the Northwest Territories, Canada, Geophys. Res. Lett., 36, L01401, doi:10.1029/2008GL035822, 2009.

Tananaev, N. I., Makarieva, O. M., and Lebedeva, L. S.: Trends in annual and extreme flows in the Lena River basin, Northern Eurasia, Geophys. Res. Lett., 43, 10764-10772, doi:10.1002/2016GL070796, 2016.

van Vliet, M. T. H., Franssen, W. H. P., Yearsley, J. R., Ludwig, F., Haddeland, I., Lettenmaier, D. P., and Kabat, P.: Global river discharge and water temperature under climate change, Global Planet. Change, 23, 450-464, 2013.

Vörösmarty, C. J. and Sahagian, D.: Anthropogenic disturbance of the terrestrial water cycle, BioScience, 50, 753-765, 2000.

Walwoord, M. A. and Striegl, R. G.: Increased groundwater to stream discharge from permafrost thawing in the Yukon River basin: Potential impacts on lateral export of carbon and nitrogen, Geophys. Res. Lett., 34, L12402, doi:10.1029/2007GL030216, 2007.
Wang, S., Huang, J., Yang, D., Pavlic, G., and Li, J.: Longterm water budget imbalances and error sources for cold region drainage basins, Hydrol. Process., 29, 2125-2136, doi:10.1002/hyp.10343, 2015.

Whittaker, R.: Assessment of the Potential Environmental Impact of the La Grande River Complex on Hudson Bay and the Inuit Coastal Communities in Northern Québec, GeoArctic-Makivik Report Final Version, 1, Calgary, Alberta, 2006.

Woo, M.-K.: Permafrost hydrology in North America, Atmos. Ocean, 24, 201-234, 1986.

Woo, M. K. and Thorne, R.: Streamflow in the Mackenzie Basin, Canada, Arctic, 56, 328-340, 2003.

Woo, M., Thorne, R., Szeto, K., and Yang, D.: Streamflow hydrology in the boreal region under the influence of climate and human interference, Philos. T. R. Soc. B, 363, 2251-2260, 2008.

Yang, D., Ye, B., and Kane, D. L.: Streamflow changes over Siberian Yenisei River Basin, J. Hydrol., 296, 59-80, 2004a.

Yang, D., Ye, B., and Shiklomanov, A.: Discharge characteristics and changes over the Ob River Watershed in Siberia, J. Hydrometeorol., 5, 595-610, 2004b.

Yang, D., Shi, X., and Marsh, P.: Variability and extreme of Mackenzie River daily discharge during 1973-2011, Quatern. Int., 380-381, 159-168, doi:10.1016/j.quaint.2014.09.023, 2015.

Yue, S., Pilon, P., Phinney, B., and Cavadias, G.: The influence of autocorrelation on the ability to detect trend in hydrological series, Hydrol. Process., 16, 1807-1829, 2002.

Zhang, X., He, J., Zhang, J., Polyakov, I., Gerdes, R., Inoue, J., and $\mathrm{Wu}, \mathrm{P} .:$ Enhanced poleward moisture transport and amplified northern high-latitude wetting trend, Nature Climate Change, 3, 47-51, doi:10.1038/nclimate1631, 2013. 